\title{
Impactos da Pandemia da Covid-19 na Gestão Financeira das Micro e Pequenas Empresas sob a Ótica de um Empresário Contábil
}

\author{
Impacts of the Covid-19 Pandemic on the Financial Management of Micro and \\ Small Enterprises from the Perspective of an Accounting Businessman \\ Impactos de la Pandemia Covid-19 en la Gestión Financiera de las Micro y \\ Pequeñas Empresas desde la Perspectiva de un Emprendedor Contable
}

\author{
Joanne Victória Cavalcanti de Oliveira Ferreira \\ Bacharel em Ciências Contábeis \\ Universidade Federal de Pernambuco (UFPE) \\ joannecavalcanti@ufpe.br \\ http://orcid.org/0000-0002-1142-885X
}

Christianne Calado Vieira de Melo Lopes

Doutora em Ciências Contábeis (UnB)

Universidade Federal de Pernambuco (UFPE) christianne.lopes@ufpe.br http://orcid.org/000-0002-7024-9843

\section{RESUMO}

Objetivo: o presente estudo tem por objetivo verificar os impactos da pandemia da COVID-19 quanto à gestão financeira das micro e pequenas empresas sob a ótica de um empresário contábil.

Método: foi revisada a literatura versando sobre os conceitos de gestão financeira, a utilização de suas ferramentas por MPEs (Micro e Pequenas Empresas) e a relação entre serviços destes empreendimentos e escritórios contábeis. Sob uma abordagem qualitativa, foi realizado um estudo documental, cuja coleta de dados ocorreu com a técnica de aplicação de uma entrevista semi-estruturada com um empresário contábil pernambucano que atua a mais de 17 anos. A partir das informações coletadas, a análise de categorias foi utilizada para o exame dos componentes textuais.

Resultados: os resultados revelam, de acordo com a percepção do empresário, que as MPEs vêm enfrentando impactos financeiros decorrentes da pandemia da Covid 19, tais como: redução na obtenção de receitas, por conta do decreto de lockdown e por não se adaptar a migração para um novo formato de vendas online; inadimplência por parte de seus clientes em geral do interior, por conta do uso do vale, seja por uso do boleto bancário como uso de cadernetas; além de obstáculos nas obtenções das linhas de crédito por parte das esferas do governo. Neste período de pandemia, também, observou-se que houve um aumento na demanda pelo apoio dos escritórios de contabilidade na tomada de decisões.

Contribuições: desse modo, a pesquisa contribui com a discussão acerca do papel do profissional contábil, enquanto provedor de serviços capaz de organizar e orientar, quanto à saúde financeira das MPEs, em período de crise, por meio do fornecimento de informações que influenciam a tomada de decisão. 
Joanne Victória Cavalcanti de Oliveira Ferreira; Christianne Calado Vieira de Melo Lopes

Relevância: o estudo se justifica pelo atual contexto de incerteza, causada pelas restrições dada a pandemia da COVID-19, os quais as MPEs tiveram que se adaptar.

Palavras-chave: Micro e Pequena Empresa; Gestão Financeira, Profissional Contábil, Pandemia da COVID-19.

\section{ABSTRACT}

Objective: this study aims to verify the impacts of the COVID-19 pandemic on the financial management of micro and small enterprises based from the perspective of an accounting businessman.

Method: was reviewed the literature established on the concepts of financial management, the use of its tools by MSEs (Micro and Small Enterprises) and the correlation between these enterprises' services and accounting offices. Under a qualitative approach, a documental analysis was carried out. The application technique for data collection was a semi-structured interview with an accounting businessman from Pernambuco State. He has more than 17 years of experience in management of accountancy companies. From the information collected, the category analysis was used to examination of the textual components.

Results: according to the businessman's perception, the results reveal that MSEs have been facing financial impacts resulting from the Covid-19 pandemic, such as: reduction in revenue, due to the lockdown decree and for not adapting to a changeover to a online sales format; nonpayment by its customers in general from countryside, due to the use of sell on credit, whether by the use of the bank slip or the use of purchase order; besides the obstacles in obtaining credit lines from the government spheres. During this period of pandemic, it was also observed that there was an increase in the demand for the support of accounting offices in decision making.

Contributions: the research contributes to the discussion about the role of the accounting professional, as a capable provider of services to organizing and guiding the financial health of MSEs, in a period of crisis, through the information provision that influence the decision-making.

Relevance: the study is justified by the current context of uncertainty, caused by restrictions given the COVID-19 pandemic, to which MSEs had to adapt.

Keywords: Micro and Small Enterprises; Financial management; Accounting Professional; COVID-19 pandemic.

\section{RESUMEN}

Objetivo: rste estudio tiene por objetivo verificar los impactos de la pandemia COVID-19 en la gestión financiera de las micro y pequeñas empresas en la perspectiva de un emprendedor contable.

Método: en este enfoque, se revisó la literatura relativa a los conceptos de gestión financiera, el uso de sus herramientas por las Micro y Pequeñas Empresas (MYPES) y la relación entre los servicios de estas empresas y las oficinas contables. Bajo un enfoque cualitativo, se llevó a cabo un estudio documental, cuya recolección de datos ocurrió mediante la técnica de aplicación de una Prosppectus - Perspectivas Qualitativas em Contabilidade e Organizações. João Pessoa. v. 1, n. 1, p. 72 107, jul/2021. 
Joanne Victória Cavalcanti de Oliveira Ferreira; Christianne Calado Vieira de Melo Lopes

entrevista semiestructurada con un empresario contable de Pernambuco con experiencia, por más de 17 años, en gestión de empresas contables. A partir de la información recopilada, se utilizó el análisis de categorías para examinar los componentes textuales.

Resultados: los resultados revelan, conforme la percepción del empresario, que las MYPES vienen enfrentando impactos económicos derivados de la pandemia Covid 19, tales como: reducción en la obtención de ingresos, debido al decreto de paralización temporal y por no adaptarse al nuevo formato de ventas en línea; incumplimiento por parte de sus clientes, en general del interior, por el uso de ventas a crédito, ya sea por el uso del boleto bancario como por el uso de libretas; así como obstáculos para la obtención de líneas de crédito de parte de las esferas gubernamentales. En este período de pandemia, también se observó que hubo un aumento en la demanda por el apoyo de las oficinas contables en la toma de decisiones.

Contribuciones: así, la investigación contribuye a la discusión sobre la relación del profesional contable, como proveedor de servicios capaz de organizar y orientar la salud financiera de las MYPES, en tiempos de crisis, mediante el suministro de informaciones que influyen en la toma de decisiones.

Relevancia: el estudio se justifica por el actual contexto de incertidumbre, provocado por las restricciones ante la pandemia de COVID-19, a la que las MYPE tuvieron que adaptarse.

Palabras clave: Micro y pequeña empresa; Gestión financiera; Profesional contable; Pandemia de COVID-19.

\section{INTRODUÇÃO}

A pandemia do coronavírus (COVID-19) impactou diversos setores da sociedade, deixando profundas marcas na esfera econômica. As políticas de isolamento social, fundamentais na preservação da vida, geraram, por outro lado, forte impacto na situação financeira das empresas, especialmente entre as de pequeno porte. Pesquisas mais recentes do SEBRAE (2021a), Serviço Brasileiro de Apoio às Micro e Pequenas Empresas, indicam que $69 \%$ dos pequenos negócios brasileiros encontram-se com dívidas em aberto, sendo que $29 \%$ das micro e pequenas empresas já estão em situação de inadimplência.

A situação das micro e pequenas empresas do país já poderiam ser consideradas preocupantes antes mesmo do início das medidas restritivas. Pesquisas indicam que aproximadamente $45 \%$ das microempresas com até dois anos fecham suas portas (SEBRAE, 2016). O comprometimento da saúde financeira das Micro e Pequenas Empresas constitui um problema para toda a economia nacional, uma vez que tais organizações representam $96,7 \%$ das empresas privadas brasileiras, além de responderem por $52 \%$ dos empregos formais existentes. No estado de Pernambuco, 98,36\% do total de empresas são MPEs (Micro e Pequenas Empresas), que empregam $58,8 \%$ do pessoal (SEBRAE, 2020a).

Muitos são os fatores que podem ser atribuídos às dificuldades enfrentadas pelas MPEs na busca pela continuidade de suas atividades, desde a instabilidade do cenário econômico até o pouco conhecimento de gestão por parte daqueles que controlam tais Prosppectus - Perspectivas Qualitativas em Contabilidade e Organizações. João Pessoa. v. 1, n. 1, p. 72 107, jul/2021. 
organizações. A Teoria da Contingência demonstra que a otimização da estrutura de uma empresa depende de fatores internos, que por sua vez são influenciados pelo ambiente externo (Donaldson, 2012), logo, a crise econômica gerada pela pandemia do Covid 19, foi um fator contingencial que, afetou o ambiente das empresas. Os fatores contingentes são aspectos que caracterizam o ambiente interno e externo das empresas e que podem influenciar sua estrutura e desempenho (Donaldson, 2012) no mercado.

Como o mercado é conduzido em grande parte pela lógica da eficiência, as empresas buscam meios de reduzir as incertezas com a finalidade de obter vantagem competitiva e aplicar os recursos (Donaldson, 2012). Um novo cenário surgiu para as empresas, com poucos recursos disponíveis, em situações de crise econômica, como a acarretada pela COVID-19, impactando diretamente na liquidez das empresas, que no caso de MPEs, já operavam em alto risco e se tornaram suscetíveis a imprevistos nos negócios (Santos, Ferreira \& Faria, 2009).

Desde o início da pandemia, muitas medidas têm sido tomadas por diversas esferas de governo para a proteção dos pequenos negócios, desde o adiamento do recolhimento de impostos até a ampliação da concessão de crédito (Governo, 2020). Todavia, as empresas ainda enfrentam grandes dificuldades para se manter em operações e muitas já encerraram suas atividades devido à crise.

Nesse contexto, gerir os recursos financeiros torna-se uma atitude decisiva no alcance da sobrevivência de pequenos empreendimentos. A contabilidade, enquanto instrumento provedor de informações torna-se decisiva no apoio à administração de recursos financeiros de seus clientes em períodos críticos. Para Mendes (2020), o cenário econômico proporcionado pela pandemia deu destaque à contabilidade, que através de informações cruciais, é capaz de ajudar seus clientes a superarem as instabilidades e melhorarem suas chances de sobrevivência.

Nesse prisma, o presente trabalho propõe-se a responder a seguinte pergunta:

\section{Como a pandemia da COVID impactou na gestão financeira das micro e pequenas empresas sob a ótica de um empresário contábil?}

O objetivo do presente estudo é verificar os impactos da pandemia da COVID-19 quanto à gestão financeira das micro e pequenas empresas sob a ótica de um empresário contábil. Diante do impacto econômico das micro e pequenas empresas, da relevância do profissional contábil e dos desafios inéditos impostos pela pandemia, o presente estudo contribui com a discussão acerca da função do contador e de como a relevância de seu trabalho é percebida na gestão financeira das empresas em contextos de crise. Para a elaboração dessa pesquisa foi realizada uma entrevista com um empresário contábil responsável pela gestão de três escritórios de contabilidade, em Pernambuco, de maneira a buscar sua percepção acerca dos impactos da crise da COVID-19 na gestão financeira das MPEs sob sua responsabilidade.

O presente trabalho apresenta-se estruturado em cinco seções, considerando-se essa Introdução, Fundamentação Teórica, Metodologia, Apresentação dos Resultados, Síntese dos Resultados e Considerações Finais. 


\section{FUNDAMENTAÇÃO TEÓRICA}

\section{1 - Teoria da Contingência}

A Teoria da Contingência se apresenta como uma das abordagens teóricas mais exploradas nos estudos de Contabilidade Gerencial e Controle (Otley, 2016). Essa lente reconhece que não há uma estrutura organizacional ou sistema de controle gerencial único, universal, que atendam todas as circunstâncias e para todas as empresas. Ao invés disso, a "melhor estrutura" (ou a organização ótima) é submetida a fatores contingenciais (Donaldson, 2012; Otley, 2016).

Alguns fatores contingenciais explorados na literatura contábil são internos à empresa, como estratégia, tamanho e tecnologia, enquanto outros são externos, como a incerteza (Freitag, Almeida \& Lucena, 2021). Os fatores contingenciais que estão presentes na pesquisa em contabilidade gerencial são variados e derivam da literatura organizacional, cuja preocupação recai sob a identificação de quais desses fatores contribuem para determinar a estrutura do sistema de controle gerencial.

A incerteza ambiental é o fator contingencial mais observado nas pesquisas em Contabilidade Gerencial (Otley, 2016), logo, devido ao cenário de crise econômica, provocado pela pandemia, elegeu-se a incerteza como fator contingencial a ser abordado neste estudo.

Simons (2005) define as incertezas estratégicas, também denominadas como incerteza ambiental, como as contingências que possam ameaçar ou invalidar a estratégia adotada pela empresa. Nesse contexto, para que a organização alcance um desempenho satisfatório em condições de grande variabilidade no ambiente, é necessária uma adaptação inteligente às novas condições dadas pela incerteza (Child, 1975), com isto, a estrutura se adequa à estratégia, e as empresas mais competitivas serão as que conseguem realizar um melhor ajuste (Donaldson, 2012). As incertezas estratégicas são particulares à cada empresa, nesse cenário as estratégias de negócios escolhidas necessitam atender de forma exclusiva cada negócio (Simons, 2005).

A palavra contingência pode ser associada a uma eventualidade, um acontecimento que pode ou não acontecer. As crises econômicas, por exemplo, podem trazer impactos às empresas de consequências incertas que não podem ser controladas por elas, como a crise enfrentada pelas organizações na atualidade relacionada com a pandemia do Covid-19.

À medida que o coronavírus continua a se espalhar, os governos no mundo todo, estão implementando medidas como a proibição de eventos, bloqueios, e desligamentos com intuito de desacelerar a disseminação da COVID-19, contudo, essas mesmas medidas, ameaçam a sobrevivência das empresas em todos os setores e indústrias em escala global. As crises não são uma novidade no mundo dos negócios, e provocam grandes recessões econômicas, e graves repercussões sociais por meio da redução da renda familiar e por conseguinte o consumo (Wenzel, Stanske \& Lieberman, 2020). 
Alguns estudos podem ser citados que investigam a capacidade de adaptação das empresas em um cenário de crise, especialmente no contexto da pandemia da Covid19. Sehnem, Magro, Mazzioni, Joveci Filho, Lunkes e Zanella (2021) investigaram sobre a capacidade de adaptação das suas organizações quanto a crise do Coronavírus junto à 409 gestores de empresas localizadas em uma região do interior de Santa Catarina. Dentre os seus achados, constataram que as empresas que estão passando por dificuldades financeiras para pagamento de dívidas, financiamentos e empregados tiveram mais perdas financeiras com a pandemia, e aquelas com menor volume de faturamento foram mais afetadas com perdas financeiras neste momento de crise.

Nassif, Correa e Rosseto (2020) constataram que as MPEs são mais suscetíveis às oscilações do mercado e à conjuntura econômica fragilizada, em decorrência da pandemia da COVID-19, o que as expôs em situações de risco.

Para Otley (2016) quando uma organização ou unidade se depara com altos níveis de incerteza, necessita de sistemas flexíveis e adaptáveis para gerenciar atividades quando ocorrerem eventos inesperados. A pandemia do Covid-19 é um evento inesperado que causa incerteza para as organizações. Nesta circunstância, as empresas precisam de maior agilidade na resposta à incerteza gerada pela crise socioeconômica onde sistemas de controles gerenciais, mesmo que sejam formais e rígidos em algumas organizações, precisaram de maior flexibilidade para responder as adversidades do momento.

Confrontadas com altos níveis de incertezas por causa do atual período pandêmico, às micro e pequenas empresas podem possuir maiores dificuldades para a adaptação à crise devido a ficarem mais suscetíveis às oscilações do mercado e à conjuntura econômica fragilizada, graças ao seu menor porte (tamanho). Entretanto, esse tipo de organização pode possuir maior agilidade na resposta à incerteza gerada pela crise, por geralmente possuírem processos de controle e gestão menos formais e mais flexíveis, ratificando o entendimento da Teoria da Contingência da Contabilidade Gerencial, conforme explicado por Otley (2016).

Diante deste novo cenário de incertezas, o próximo item destaca o impacto da Covid-19 nas MPEs.

\subsection{Micro e Pequenas Empresas: o impacto da Covid-19}

A presença de pequenos empreendimentos na história do Brasil remonta ao período colonial, a partir do século XVI, durante o qual os pequenos produtores cuidavam do abastecimento do mercado interno e garantiam a subsistência da população. Segundo Prado Júnior (1981), o próprio proprietário trabalhava nessas lavouras especializadas em atender às necessidades alimentares da colônia exportadora, contando com poucos auxiliares. A produção voltada ao mercado interno impactou a economia do período colonial e ampliou oportunidades para o investimento por pequenos empresários, ainda que estes tivessem que lidar com as proibições da Coroa portuguesa (Souza, Machado \& Oliveira, 2007).

Prosppectus - Perspectivas Qualitativas em Contabilidade e Organizações. João Pessoa. v. 1, n. 1, p. 72 107, jul/2021. 
Ao longo do tempo, a presença das pequenas organizações econômicas tornouse ainda mais notável,em especial a partir do crescimento do empreendedorismo. A criação de instituições como o SEBRAE (Serviço Brasileiro de Apoio às Micro e Pequenas Empresas) foi decisiva para o aumento das atividades empreendedoras no Brasil nas décadas de 1980 e 1990. Com essa expansão e o crescente papel das referidas organizações na economia, políticas públicas vêm sendo adotadas para garantir proteção especial que assegure a sobrevivência dessas entidades (Ferreira, Oliva, Santos,Grisi \& Lima, 2012).

Uma das mais importantes medidas adotadas foi a promulgação do Estatuto Nacional da Microempresa e Empresa de Pequeno Porte, ou Lei Complementar no $^{\text {o }}$ 123/2006. Essa lei estabelece normas gerais rentes ao tratamento diferenciado e favorecido a ser atribuído às microempresas e empresas de pequeno porte, como regime único de arrecadação, acesso ao crédito facilitado, preferências nas compras pelo Poder Público, dentre outras medidas (Brasil, 2006).

Para classificar empresas como sendo Microempresa (ME) ou Empresa de Pequeno Porte (EPP), diferentes critérios são passíveis de adoção. Nos termos da já citada Lei no 123/2006, a classificação deve ser feita com base na receita bruta anual, sendo microempresa a que aufere receita bruta anual não superior a $R \$ 360.000,00 \mathrm{e}$ empresa de pequeno porte, a que aufere entre $\mathrm{R} \$ 360.000,00$ e $\mathrm{R} \$ 4.800 .000,00$. O método de classificação adotado pelo SEBRAE, por sua vez, baseia-se no número de funcionários e setor de atuação da empresa, conforme segue.

Tabela1

Critérios de Classificação das Microempresas e Empresas de Pequeno Porte

\begin{tabular}{|c|c|c|c|}
\hline CLASSIFICAÇÃO & Lei no $\mathbf{1 2 3 / 2 0 0 6}$ & $\begin{array}{c}\text { SEBRAE } \\
\text { Comércio/Serviços }\end{array}$ & SEBRAE Indústria \\
\hline Microempresa & RBA até $\mathrm{R} \$ 360.000,00$ & Até 9 funcionários & Até 19 funcionários \\
\hline Empresa de Pequeno & RBA entre & Entre 10 e 49 & Entre 20 e 99 \\
Porte & $\mathrm{R} \$ 360.000,00 \mathrm{e}$ & funcionários & \\
& $\mathrm{R} \$ 4.800 .000,00$ & & \\
\hline
\end{tabular}

Fonte: Adaptado de SEBRAE (2013) e Lei nº 123/2006 (Brasil, 2006).

Apesar das políticas públicas de facilitação às MPEs, os índices de mortalidade atribuídos a essas organizações chamam a atenção. Apesar de não ser possível a atribuição de uma causa única para o fracasso de MPEs, estudos apontam fatores diversos que podem contribuir para a mortalidade dos pequenos empreendimentos. Bonacim, Cunha e Correia (2009) apontam a falta de informações sobre o negócio e o pouco planejamento administrativo como responsável pelo encerramento das MPEs.Já Ferreira, Oliva, Santos, Grisi e Lima (2012) associam a ausência de planejamento nos negócios com a mortalidade precoce; Roratto, Dias e Alves (2017) indicam que a falta de clientes e a falta de capital de giro, associada com uma gestão financeira frágil são motivos que geralmente levam ao fechamento das organizações estudadas. 
Conforme pontuado, os pequenos negócios brasileiros já são caracterizados por um histórico de enfrentamento de obstáculos para manter suas operações em continuidade. A partir do início do ano de 2020, com a chegada do coronavírus e as consequentes medidas de enfrentamento que provocaram restrições nos mais diversos segmentos econômicos, a situação das MPEs apenas se agravou (Belizário \& Almeida, 2020).

Dados do SEBRAE (2021b) apontam que, dos 17,77 milhões de pequenos empreendimentos existentes no país, 12,92 milhões encontram-se entre os segmentos mais vulneráveis à crise atual, o que corresponde a cerca de $72,7 \%$ do total. O mesmo painel de informações aponta que o comércio é o setor que vivencia a maior insegurança, e que entre os segmentos, o varejo tradicional e a construção civil são os mais suscetíveis aos efeitos da crise.

Desde o início da pandemia, muitas medidas importantes vêm sendo tomadas com o intuito de dirimir os efeitos nocivos para a economia, e mais especificamente, para as organizações de menor porte. Dentre elas, destacam-se a disponibilização e acesso facilitado a linhas de crédito, a prorrogação do pagamento de diversos tributos (SEBRAE, 2020b), bem como as opções envolvendo os funcionários, na forma da suspensão temporária de contrato ou redução proporcional da jornada e salário, tendo por finalidade a preservação dos empregos (Jornal, 2021).

Apesar das ações tomadas, de acordo com o SEBRAE (2020c), 27\% das MPEs declararam não ter condições de realizar nenhum tipo de investimento em 2021, sendo que $10 \%$ guardam dinheiro para alguma emergência. Esses números indicam a insegurança e o alto risco percebido pelo pequeno empreendedor em decorrência do contexto atual. Com o crescente aumento nos números de casos da pandemia e a retomada das medidas restritivas em diversas unidades federativas, os pequenos negócios se encontram em situação de maior vulnerabilidade novamente.

Empreendimentos de pequeno e médio porte vêm apresentando maiores necessidades de apoio em aspectos como a melhora no marketing e vendas, na gestão dos fluxos de caixa e na migração para ambientes digitais (Panorama, 2020). Depreendese que, devido à redução do fluxo de pessoas decorrente da crise sanitária, as empresas não têm vendido seus bens e serviços, e agora encontram dificuldades para realizar essas vendas de maneira virtual, o que constitui um impacto direto em seu caixa.

Bernardes, Silva e Lima (2020), discutiram os impactos financeiros da Covid-19 nos negócios e ressaltam que, especialmente, os pequenos negócios registraram queda de $88 \%$ no faturamento, sendo os segmentos da educação, turismo, economia criativa, moda e beleza os mais impactados, além de muitos desses pequenos empreendimentos não estarem preparados para o comércio eletrônico.

Vale, Sousa, Oliveira, Regis e Lima (2021) ratificam o ressaltado por Bernardes, Silva e Lima (2020) quanto ao ramo da beleza ser um dos segmentos mais afetados pela pandemia da Covid-19, com redução de faturamento da ordem $69 \%$, citando dados do SEBRAE. Vale, et al. (2021) analisaram o grau de resiliência de dez microempreendedoras do ramo da beleza da cidade de Mossoró-RN. Dentre as suas Prosppectus - Perspectivas Qualitativas em Contabilidade e Organizações. João Pessoa. v. 1, n. 1, p. 72 107 , jul/2021. 
constatações, os autores encontraram que apenas duas das dez entrevistadas enquadraram-se na categoria de alta resiliência.

Reduções da atividade econômica e, por conseguinte, das vendas, repercutem diretamente na receita das operações, exigindo medidas de precaução que assegurem a preservação da liquidez da empresa (Zdanowicz, 1995). Diante do ambiente de incerteza ambiental gerado pela pandemia, as MPEs precisam ser ágeis para se adaptarem as adversidades surgidas a cada dia em suas empresas, reforçando mais uma vez a necessidade de uma gestão financeira capaz de controlar a utilização dos recursos, minimizando os impactos externos e potencializando as chances de sobrevivência dos pequenos empreendimentos.

\subsection{Ferramentas Contábeis Utilizadas na Gestão Financeira}

A administração financeira é um processo essencial para o desenvolvimento e continuidade das atividades dos empreendimentos. Para Gitman (2010), a administração financeira refere-se às atribuições da pessoa do administrador financeiro, responsável pela gerência ativa dos assuntos financeiros da organização. De modo similar, Kuhn (2012) defende que a administração financeira constitui um processo, na forma de atos administrativos ou tomada de decisões, que implica aspectos de aquisição e aplicação dos recursos financeiros de uma empresa.

O objetivo mais geral da gestão financeira é a agregação de valor para o proprietário do negócio, compreendendo ainda os objetivos de sobrevivência, evitar problemas financeiros, maximização das vendas, minimização dos custos, dentre outros. O gestor das finanças de uma empresa deve preocupar-se basicamente com seu orçamento de capital, estrutura de capital e administração do capital de giro (Ross, Westerfield, Jaffe \& Lamb, 2015).

A tomada de decisões financeiras em uma empresa é orientada pela maximização da riqueza, buscando a administração financeira diminuir os riscos e alocar os recursos de maneira mais eficaz (Assaf Neto, 1997). De acordo com Kummer, Bromberger e Dondoni (2011), as ferramentas disponibilizadas pela gestão de recursos financeiros têm o papel de coordenar os sistemas de tomada de decisão, através do fornecimento de informações que permitam ao gestor agir de maneira proativa ao confrontar o planejamento com a realidade. Similarmente, Gitman (2010) afirma que o responsável pelas finanças de uma empresa tem como atividade precípua a tomada de decisões de investimento e de financiamento.

É de conhecimento popular que muitos empreendimentos, destacando-se os de menor porte, tomam decisões tocantes ao negócio com base em sua intuição ou experiências anteriores, dispensando o uso de ferramentas eficazes e comprometendo os recursos financeiros da organização. Logo, a maioria das MPEs termina aplicando técnicas rudimentares de gestão, contabilidade e controle, mas que necessitam de técnicas voltadas para a contabilidade gerencial, assim como as médias e grandes organizações (Feil \& Haberkamp, 2020). O desequilíbrio financeiro vivenciado por 
algumas empresas é decorrente da ausência de controle em suas finanças, o que as afasta do alcance de bons resultados (Fiorelli, 2016).

Conforme destacado por Gazzoni (2003), o chamado empirismo administrativo não cabe mais em cenários de competitividade nos quais se faz necessária uma gestão mais eficiente dos recursos. Múltiplos instrumentos podem ser utilizados nos processos relativos às finanças de uma organização e mostram-se imprescindíveis no fornecimento de informações capazes de subsidiar a tomada de decisão.

Considerando que o principal objetivo da contabilidade é o fornecimento de informações relevantes na tomada de decisões, o profissional contábil é figura competente para ofertar diversas ferramentas de gestão financeira a seus clientes. Alguns dos instrumentos de gestão financeira frequentemente apontados como eficientes e que podem ser fornecidos por um profissional contábil são destacados a seguir: análise das demonstrações contábeis, o capital de giro, o orçamento e o fluxo de caixa.

Como já se sabe, o principal objetivo da contabilidade é o fornecimento de informações, geralmente contidas em relatórios e demonstrações contábeis. A análise das demonstrações contábeis é um instrumento de gestão capaz de fornecer ao gestor uma melhor visão acerca das tendências de negócios e objetiva o alcance da correta obtenção e aplicação de recursos (Silva, Couto \& Cardoso, 2016). De acordo com Brizolla (2008), as demonstrações financeiras básicas são o balanço patrimonial e a demonstração do resultado do exercício.

O Balanço Patrimonial (BP) é a demonstração contábil responsável pela apresentação da posição patrimonial e financeira de uma organização em determinada data (Fipecafi, 2018). Consiste em um dos relatórios financeiros mais importantes, e dele muitas informações relevantes podem ser extraídas, destacando-se os aspectos da liquidez, dívida versus capital próprio e valor versus custo (Ross, Westerfield, Jaffe \& Lamb, 2015). Por meio da análise das demonstrações contábeis, esses aspectos são medidos por índices financeiros, que indicam o desempenho da organização.

A liquidez de uma empresa indica a capacidade de saldar suas obrigações na medida em que vencem, ou a facilidade com que as contas podem ser pagas dentro do prazo (Gitman, 2010). Por sua vez, os índices de dívida versus capital próprio, também chamados de índices de estrutura e endividamento, medem respectivamente o quanto a empresa detém de capital de terceiros e o quanto lhe pertence. Por fim, o valor versus custo representa a distinção entre os números contábeis pelos quais se registram os ativos da empresa e o valor de mercado, geralmente não equivalentes (Ross, Westerfield, Jaffe \& Lamb, 2015).

A Demonstração do Resultado do Exercício (DRE) representa o confronto entre despesas e receitas de um dado período pelo regime de competência, que pode resultar em lucro ou prejuízo. Segundo Brizolla (2008), a DRE retrata o fluxo econômico, que pode não coincidir com o fluxo monetário, ou o que há disponível em caixa. Tanto o $\mathrm{BP}$ quanto a DRE podem ser analisados a partir dos conceitos de análise horizontal e vertical. A análise vertical consiste em identificar qual o percentual de cada componente Prosppectus - Perspectivas Qualitativas em Contabilidade e Organizações. João Pessoa. v. 1, n. 1, p. 72 $107, \mathrm{jul} / 2021$. 
em relação ao todo da demonstração financeira que representa, dentro de um mesmo período, enquanto a análise horizontal preocupa-se com a evolução dos resultados ao longo do tempo (Camargo, 2018).

Ainda que as micro e pequenas empresas não sejam legalmente obrigadas a tornar públicas suas demonstrações contábeis, é fundamental que tais relatórios sejam elaborados e utilizados para fins gerenciais. Outro ponto que se destaca é o acompanhamento do capital de giro nas micro e pequenas empresas.

De acordo com Brigham (1999), o capital de giro consiste em um investimento da empresa em ativos de curto prazo, na forma de disponibilidades, contas a receber e estoques. Segundo Gitman (2010), na condução normal das atividades de uma empresa, o capital de giro constitui uma porção de investimento que transita de um elemento circulante a outro, geralmente na conversão de caixa para estoques, destes para recebíveis, e por fim, quando do recebimento, de volta ao caixa. Assim, o que retorna ao caixa da empresa é destinado a liquidar o passivo circulante, que são as dívidas de curto prazo da empresa.

Na concepção de Kuhn (2012), a administração do capital de giro opera nas áreas relacionadas à gestão de estoques, de créditos a receber, das disponibilidades e dos créditos a pagar. Nesse sentido, aspectos como prazo de recebimentos e pagamentos, bem como quantidade e tempo de estocagem, devem ser levados em conta quando se trata da análise do capital de giro.

Um dos conceitos mais tradicionais dentro da administração do capital de giro é o de capital circulante líquido, representado pela equação $C C L=A C-P C$, onde se subtrai do ativo circulante o que existe em passivo circulante em determinado momento. Uma empresa vivencia equilíbrio financeiro quando suas obrigações financeiras possuem lastro em ativos com prazos similarmente curtos de conversão em caixa (Ferreira, Macedo, Sant'anna, Longo \&, Barone, 2011).

Quanto maior o resultado de capital de giro líquido, menor o risco de a empresa não conseguir saldar suas dívidas, tornando-se insolvente. Assim, o ideal é que as empresas busquem manter uma margem de ativo circulante sempre superior ao passivo circulante, de modo a cobrir as saídas de recursos (Gitman, 2010).

Quando se trata de micro e pequenas empresas, é essencial que seja feito um acompanhamento de seu capital de giro, uma vez que este sofre impacto contínuo das mudanças, tanto internas quanto externas (Ferreira, Macedo, Sant'anna, Longo \&, Barone, 2011). Além do mais, a escassez de recursos nas MPEs é mais acentuada, o que pode levar a necessidades de financiamento. Uma vez que o acesso a financiamentos de longo prazo por pequenos empreendimentos é pouco expressivo, cria-se a necessidade de se recorrer com frequência a empréstimos de curto prazo para cobrir a falta de recursos, o que tem impacto direto no capital de giro (Brito, 2005).

Quanto à utilização do orçamento pelas empresas, há uma estreita ligação deste com o capital de giro, uma vez que é relevante observar a necessidade dos recursos circulantes e suas fontes de financiamentos adotadas (Ishisaki, 2003). De acordo com 
Zdanowicz (1995), o orçamento consiste em um instrumento que contém descrições acerca do plano geral de operações e/ou de investimentos de uma organização, guiado pelos objetivos e metas definidas pela administração para um certo período.

A elaboração do orçamento parte dos comportamentos passados e olha para possíveis mudanças futuras, quantificando, econômica e financeiramente, as atividades da empresa, funcionando como uma previsão conforme a qual será realizada a tomada de decisões (Andrade, 2020).

Segundo Corrêa (2010), o orçamento tem por objetivo nortear as metas de cada área de uma empresa, funcionando como uma meta a ser atingida, permitindo que cada setor compreenda seu papel no alcance do objetivo maior da organização.

Apesar de funcionar como uma ferramenta de planejamento, o orçamento precisa ser acompanhado através de um controle. Sabe-se que imprevistos e situações externas podem modificar os planos traçados pela empresa, os quais precisam ser alterados. Como em todo processo administrativo, o controle do orçamento oferece um feedback, servindo de base para a reestruturação do que foi planejado, se necessário (Carneiro, 2015).

A não utilização ou a utilização apenas parcial dos controles de orçamento em uma empresa são um obstáculo para a gestão de MPEs. Conhecimento limitado e utilização inadequada do orçamento constituem, para empresas de menor porte, as maiores dificuldades para a promoção de ações de correção quando do confrontamento entre valores orçados e realizados (Söthe \& Kamphorst, 2009).

No entanto, existe entre empreendimentos de pequeno porte a visão de que o orçamento é um instrumento muito sofisticado e que só é aplicável para empresas maiores (Ishisaki, 2003). Ainda de acordo com Zdanowicz (1995), geralmente empresas de maior porte precisam seguir a totalidade do sistema orçamentário, enquanto micro e pequenas empresas concentram seus esforços no orçamento de caixa, pela sua constante necessidade de disponibilidades. Logo, torna-se relevante tratar sobre a gestão do fluxo de caixa nas empresas.

O fluxo de caixa pode ser definido como o conjunto de movimentações financeiras, na forma de entrada e saída de recursos, ocorridas na conta de caixa e equivalentes de caixa de uma entidade durante um determinado período. De acordo com o Pronunciamento Técnico CPC 03 - Demonstração dos Fluxos de Caixa (CPC, 2010), o caixa consiste no numerário em espécie e nos depósitos bancários disponíveis, enquanto os equivalentes de caixa correspondem a aplicações financeiras de curto prazo, alta liquidez, e sujeitas a um insignificante risco de mudança de valor.

Para Hoss (2018), a gestão do fluxo de caixa visa fornecer informações sobre o histórico de movimentações de caixa de uma organização, proporcionando uma base para a avaliação da capacidade de geração de caixa e das suas necessidades de utilização. Segundo o autor, essas informações permitem uma melhor compreensão da estrutura financeira da entidade, a partir do conhecimento de sua liquidez e solvência. 
Zdanowicz (1995) afirma que um dos principais objetivos do fluxo de caixa é a otimização de recursos, sejam próprios ou de terceiros em poder da empresa, aplicandoos nas opções mais rentáveis. Destarte, depreende-se que os fluxos de caixa têm por objetivo mais geral informar acerca da situação financeira da empresa, indicando as transações que tiveram impacto nas disponibilidades, e se há sobras ou necessidade de obter mais caixa ao fim do período estudado.

Uma gestão de caixa eficiente, considerada aquela capaz de atender a seus objetivos, torna-se uma ferramenta de grande potencial para o planejamento e a tomada de decisões em meio a cenários de incerteza. Segundo Silva e Neiva (2014), ao planejar o fluxo de caixa, a organização entenderá, com antecedência, as necessidades financeiras para saldar os compromissos costumeiros, levando em conta os prazos para pagamento. Com base nesse planejamento, o administrador financeiro busca organizar os recursos a serem destinados ao pagamento de modo a evitar a escassez de caixa no fim do período.

Apesar de seu papel no sucesso da gestão financeira de uma empresa, o planejamento, por si só, não é suficiente. Além de planejar as movimentações de caixa para um dado período, é imprescindível que se desenvolva, concomitantemente, um controle que permita o acompanhamento em tempo real das operações e os ajustes a serem realizados no plano (Hoss, 2018). Similarmente, Fiorelli (2016) afirma que o controle de revisão deve ser adotado, tanto para a confrontação do caixa planejado com o caixa realizado, quanto devido às oscilações de mercado a que todas as organizações estão sujeitas.

Com planejamento e controle financeiros alinhados, a empresa consegue fruir de todos os benefícios do fluxo de caixa, enquanto instrumento capaz de auxiliar na gestão de suas disponibilidades.

\subsection{Gestão Financeira nas Micro e Pequenas Empresas}

Há muito, a contabilidade deixou de ser uma mera ferramenta de escrituração, limitada a registrar fatos e atender a obrigações fiscais. Para Iudícibus, Martins e Carvalho (2005), hoje a Contabilidade apresenta-se como uma forma eficaz de avaliação do desempenho de uma entidade ou de seu gestor, além de ser fundamental na tomada de decisões econômico-financeiras e na prestação de contas perante a sociedade.

Santos, Ferreira e Faria (2009) apontam que há certa carência no uso de instrumentos gerenciais pelas MPEs, sendo que muitas vezes empresas contábeis não fornecem aos seus clientes esse tipo de serviço ou os próprios clientes não sentem necessidade dessas informações. O estudo realizado por Dominguez, Tinoco, Yoshitake, Paulo e Claro (2017), afirma que os gestores precisam de uma assessoria contábilfinanceira de qualidade, nas micro e pequenas empresas, de tal maneira que seja destacada, a importância do fluxo de caixa e o gerenciamento do capital de giro.

Segundo Brizolla (2008), a complexidade da economia moderna e a escassez de recursos exige dos gestores de negócios eficiência na escolha entre alternativas, o que só pode ser feito a partir de dados contábeis.

Prosppectus - Perspectivas Qualitativas em Contabilidade e Organizações. João Pessoa. v. 1, n. 1, p. 72 $107, \mathrm{jul} / 2021$. 
Nesse contexto, a Contabilidade passa aos poucos a ocupar uma função mais direcionada ao suporte gerencial nas empresas, e pode ser essencial para os pequenos empreendimentos, que conforme já citado, costumam enfrentar dificuldades com a gestão de seus recursos financeiros.

Em um estudo com pequenos mercados do município do Recife (PE), Miranda, Libonati, Freire e Saturnino (2008) indicam que parcela considerável dos entrevistados percebem o contador apenas como provedor de serviços relacionados a impostos e encargos sociais. Por outro lado, grande parte dos entrevistados também se mostrou dispostos a pagar mais em troca de informações úteis à tomada de decisões, assim consideradas aquelas capazes de melhorar o gerenciamento do negócio.

Para Silva, Miranda, Freire e Anjos (2010), nas micro e pequenas empresas percebe-se uma maior ênfase em informações relacionadas a aspectos financeiros, principalmente devido à preocupação com a economia de recursos. De acordo com Corrêa (2010), parte considerável dos pequenos negócios, inclusive os administrados pelos próprios proprietários, vêm utilizando ferramentas de apoio à tomada de decisão, bem como procurando suporte das informações contábeis.

O estudo de Feil \& Haberkamp (2020), destaca as ferramentas mais utilizadas na prática empresarial das MPEs pelos gestores de Micro e Pequenas Empresas (MPEs), sendo as vendas, a ferramenta operacional, e o fluxo de caixa, a ferramenta gerencial. Em um cenário como o vivenciado na crise econômica proporcionada pelo coronavírus, grande parte dos pequenos empreendimentos consideram positivos os efeitos dos serviços contábeis recebidos, indicando o papel indispensável da contabilidade no alcance de sua sobrevivência (Mendes, 2020).

Nesse sentido, a gestão dos recursos de pequenas empresas pode ser otimizada a partir do reconhecimento da importância do controle financeiro e do assessoramento de um profissional especializado, como é o caso do contador. Essa tendência da valorização dos serviços de assessoramento contábil em períodos de crise cria, para o contabilista, um leque de novas funções, e para seus clientes, uma oportunidade de organizar sua gestão de modo eficiente, gerando um ambiente de adaptação para ambas as partes devido às incertezas estratégicas surgidas diante do novo contexto.

\section{METODOLOGIA}

O presente trabalho caracteriza-se como uma pesquisa exploratória no que se refere aos seus objetivos. Segundo Gil (2002), a pesquisa exploratória almeja proporcionar uma visão geral e aproximativa no que se refere a um determinado fato. Assim, o presente estudo torna-se exploratório na medida em que busca proporcionar uma melhor compreensão dos impactos da crise atual quanto à gestão financeira das MPEs em meio à pandemia da COVID-19, o que deflagrou um ambiente de incerteza nos negócios, considerando que se trata de um novo cenário, ainda pouco explorado. 
No que tange à abordagem adotada, a pesquisa caracteriza-se como qualitativa, uma vez que busca compreender informações subjetivas através de análise e interpretação, bem como não faz uso de instrumentos estatísticos.

A primeira fase da pesquisa consistiu na pesquisa bibliográfica, por meio de livros, monografias, dissertações e artigos online, que serviu para a elaboração do referencial teórico. Fontana (2018) define pesquisa bibliográfica como aquela relacionada à leitura, análise e interpretação da literatura disponível sobre um tema, servindo como subsídio para a fundamentação teórica do estudo. Nesse sentido, foram realizadas pesquisas bibliográficas sobre a teoria da contingência, gestão financeira e os impactos econômicos da COVID-19, bem como a oferta de serviços contábeis a MPEs no que tange à administração de seus recursos.

A partir do referencial teórico construído, buscou-se a adoção da metodologia mais adequada para o atendimento dos objetivos propostos e verificou-se que a estratégia da pesquisa documental seria apropriada. Dresch, Lacerda e Antunes Júnior (2015) classificamos documentos primários como aqueles que foram criados pelo próprio pesquisador. $\mathrm{O}$ uso de documentos primários e secundários permite compreender as organizações de forma contextualizada, ao analisar os documentos de forma histórica e sociocultural (Sá-Silva, Almeida \& Guindani, 2009). Nesse sentido, a entrevista é considerada um documento produzido pelo pesquisador, e permite alcançar o objetivo proposto de verificar os impactos da pandemia da COVID-19 quanto à gestão financeira das MPEs na ótica de um empresário contábil.

Para a coleta de dados no presente estudo, foi desenvolvido um roteiro de entrevista semiestruturada, aplicada com um empresário contábil que dirige escritórios de contabilidade em Pernambuco. O roteiro de entrevista foi desenvolvido com respaldo no referencial teórico levantado e foram divididas as questões em três categorias, a saber: gestão empresarial de MPEs; gestão financeira: contexto geral e; por fim a gestão financeira: no contexto da pandemia.

Após a elaboração das questões, estas foram submetidas à apreciação de dois especialistas, por meio de correio eletrônico, para que fossem validadas. A escolha dos profissionais contábeis responsáveis pela validação do instrumento se deu pela sua capacidade de colaboração com os objetivos da pesquisa, baseando-se em sua experiência profissional.

$\mathrm{O}$ profissional " $\mathrm{A}$ " sugeriu que fossem incluídas questões referentes à inadimplência por parte das MPEs clientes no pagamento de honorários devido ao escritório de contabilidade, bem como questão referente aos contratos de trabalho dos funcionários das referidas MPEs. Por sua vez, o profissional "B" deu como sugestão a correção da redação das questões de forma que estas ficassem mais claras e precisas no momento da aplicação da entrevista.

Com o roteiro de entrevista validado, procedeu-se à coleta de dados. A entrevista foi realizada em abril de 2021, através de reunião online, via google meet, e teve duração aproximada de 53 minutos, tendo sido utilizada uma ferramenta de gravação. 
O entrevistado é um empresário contábil formado em Ciências Contábeis e possui Pós-Graduação em Planejamento Tributário. Possui 17 anos de experiência profissional na área e trabalha como gestor de empresa contábil há 10 anos. Atualmente, é o proprietário e responsável pela direção de quatro empresas, em Pernambuco, sendo três escritórios de contabilidade propriamente ditos e, o último trata-se de uma empresa de capacitação e desenvolvimento de pessoas na profissão contábil.

Esse empresário possui sob sua gestão, duas Empresas Prestadoras de Serviços Contábeis em funcionamento no município de Recife (PE), que conta com 26 colaboradores, e outra no interior do Estado de Pernambuco no município de Surubim (PE), no interior do estado com 38 colaboradores. O quantitativo médio de clientes atendidos pelos três escritórios sob direção do entrevistado, soma aproximadamente 500 empresas, sendo que destas, cerca de $90 \%$ são classificadas como micro e pequenas empresas, o que corresponderia a 450 empresas.

A escolha do entrevistado justifica-se pela sua experiência enquanto empresário contábil que gerencia três escritórios de contabilidade, bem como por suas recentes experiências na prestação de serviços de assessoria e consultoria na gestão de MPEs em meio à pandemia da COVID-19.

Após a realização da entrevista, foi iniciada a etapa de análise das informações coletadas. Para Bardin (1977), a análise de categorias consiste no desmembramento do texto em categorias, com base nos temas abordados durante a revisão de literatura. Com a autorização do entrevistado, o áudio resultante da gravação da entrevista foi transcrito de forma literal. Após a transcrição, enviou-se as informações coletadas para que o entrevistado pudesse validar o conteúdo, de maneira que foram dispostas com base na divisão do conteúdo (categorias temáticas e subcategorias), descritas na tabela 2.

Tabela 2

Categorias e Subcategorias Abordadas na Pesquisa

\begin{tabular}{|c|l|}
\hline CATEGORIAS & \multicolumn{1}{c|}{ SUBCATEGORIAS } \\
\hline GESTÃO EMPRESARIAL DE MPEs & $\begin{array}{l}\text { - Percepção das principais dificuldades que MPEs } \\
\text { enfrentam na condução de seus negócios; } \\
\text { - Percepção do conhecimento em gestão pelos clientes } \\
\text { MPEs; }\end{array}$ \\
\hline GESTÃO FINANCEIRA: CONTEXTO & $\begin{array}{l}\text { - Aceitação de consultorias/assessorias pelas MPEs } \\
\text { - Instrumentos de gestão financeira ofertados } \\
\text { GERAL }\end{array}$ \\
$\begin{array}{l}\text { - Utilização de demonstrações contábeis e orçamentos } \\
\text { pelas MPEs }\end{array}$ \\
\hline GESTÃO FINANCEIRA: CONTEXTO DA \\
PANDEMIA & $\begin{array}{l}\text { - Identificação dos setores mais afetados } \\
\text { - Identificação das principais dificuldades percebidas } \\
\text { - O papel do profissional contábil na tomada de decisões }\end{array}$ \\
\hline
\end{tabular}

Organizados os dados coletados na entrevista em temas, procedeu-se à análise das respostas e a comparação dos conteúdos obtidos com a fundamentação teórica previamente levantada, realizando-se as interpretações.

Prosppectus - Perspectivas Qualitativas em Contabilidade e Organizações. João Pessoa. v. 1, n. 1, p. 72 107, jul/2021. 


\title{
4. APRESENTAÇÃO DOS RESULTADOS
}

\subsection{Gestão Empresarial de MPEs}

O objetivo deste tópico consistiu em identificar a percepção do empresário contábil quanto à gestão empresarial de micro e pequenas empresas, abarcando as dificuldades percebidas em contextos normais e o conhecimento dos clientes quanto à gestão financeira.

Quando questionado sobre as principais dificuldades percebidas na condução dos negócios de clientes enquadrados como MPEs, o empresário contábil citou alguns fatores que considera mais estruturantes e impactantes. Primeiro, foi citada a falta de profissionalização na gestão, conforme segue:

\begin{abstract}
Eu enxergo que nessas micro e pequenas empresas, a grande maioria são empresas familiares [...] então, eles têm uma característica de delegar cargos de gestão e cargos de confiança para parentes, pessoas do mesmo vínculo familiar, pelo critério de confiança. [...] E, muitas vezes, os critérios técnicos acabam ficando em segundo plano. É a falta de profissionalização na gestão, a busca por profissionais capacitados para ocupar o cargo. Se um familiar se enquadra nos requisitos da vaga, ótimo, mas que isso não fosse o requisito principal.
\end{abstract}

De acordo com o relato do entrevistado, a questão dos vínculos familiares tornase um problema quando micro e pequenas empresas se baseiam na necessidade por parte de algum familiar, que será contratado com base exclusiva nesse critério. $\mathrm{O}$ empresário contábil ainda complementa que, após contratado, muitas vezes esse familiar não tem o estímulo para aprender a exercer suas funções ou a cobrança requerida pelo cargo que ocupa, o que se torna um grande problema para a empresa.

Quanto a outra dificuldade percebida na gestão de MPEs, o empresário contábil levantou a ausência de análises de dados do negócio, e devido a já citada falta de profissionalização costumeira, o hábito dos empresários de gerirem exclusivamente pelo feeling, ou intuição. Foi alegado ainda que a falta dessas informações decorre de pouca organização por parte dos gestores de MPEs nos registros de informações financeiras, sendo considerados de difícil acesso dados principalmente relativos às movimentações de caixa e bancos.

Para o profissional, frequentemente os pequenos empresários não percebem a importância dos dados para medir o seu negócio e tomar decisões mais precisas. $\mathrm{O}$ entrevistado exemplifica:

De repente, o faturamento caiu. [...] Se, de repente, ele passasse a analisar quais foram os itens que ficaram menos vendidos [...]. Pode ser que dentro daquele mesmo negócio, tenham itens que ele tenha vendido mais do que em outras épocas. Então, com dados na mão, ele poderia dizer 'olha, meus números mostram que, por conta do cenário que estou vivendo, esses itens estão ficando menos atrativos para meu público-alvo, e esses aqui estão se tornando mais atrativos [...], vou concentrar o pouco dinheiro que está entrando, e comprar os itens que estão saindo mais' [...] Só que como ele não tem um número, principalmente um número atualizado para tomar decisão, ele fica no feeling.

Prosppectus - Perspectivas Qualitativas em Contabilidade e Organizações. João Pessoa. v. 1, n. 1, p. 72 107, jul/2021. 
Neste ponto, o resultado vai ao encontro da pesquisa realizada por Bonacim, Cunha e Correia (2009) com empreendedores de MPEs que tiveram suas atividades encerradas. Os autores concluíram que a falta de informações sobre o negócio e o pouco planejamento administrativo foram decisivos para a mortalidade das empresas pesquisadas.

Na percepção do empresário contábil, micro e pequenos empresários precisam conhecer dados do negócio, como produtos mais vendidos ou com maior margem, prazo médio de pagamentos e de recebimentos, e até mesmo os próprios clientes enquanto público-alvo. Para o empresário contábil, quando o micro e pequeno empresário dispõe de dados reais e passíveis de serem acompanhados em um curto espaço de tempo, ele forma uma munição para tomar decisões de maneira mais estratégica.

No que se refere às dificuldades, o empresário contábil citou que existem diversas outras, como dificuldades de acesso ao crédito ou de acesso a linhas de investimento. No entanto, de acordo com o profissional, ao profissionalizar cargos de gestão, estruturar a sucessão da empresa e analisar os dados do negócio, a empresa encontra-se em melhores condições de organização para lidar com os demais problemas.

Quando questionado sobre o nível de conhecimento em práticas de gestão financeira dos clientes MPEs, o entrevistado afirmou que grande parte não domina esse campo. Segundo o empresário contábil, existe, na maioria das vezes, um conhecimento básico por parte dos gestores, mas não é algo que alcance um nível estratégico. Em outro estudo indicativo da causa de mortalidades de micro e pequenos empreendimentos, a gestão financeira frágil, ao impactar no capital de giro, é apontada como um dos fatores capazes de provocar o encerramento de atividades dessas organizações (Roratto, Dias \& Alves, 2017).

\subsection{Gestão Financeira: contexto geral}

Este tópico tem por objetivo identificar a percepção do empresário contábil quanto a aspectos gerais referentes à gestão financeira em micro e pequenas empresas, bem como a oferta de ferramentas de apoio pelos escritórios de contabilidade pesquisados e sua utilização pelos clientes.

Para descobrir a percepção do entrevistado quanto à gestão de caixa nas MPEs clientes de suas empresas contábeis, foi inicialmente direcionada uma questão relativa à existência, ou não, de separação dos caixas das empresas em relação ao caixa de seus respectivos proprietários, em referência ao princípio da entidade. O profissional comentou que apesar de existir algumas vezes um apontamento, muitas vezes os sócios necessitam de uma determinada renda e a extraem do patrimônio da organização sem saber se ela tem condições. Em outro trecho, o empresário contábil complementa:

Muitas vezes o empresário não sabe, se eu perguntar [...] 'olha, quanto você tira todo mês da sua empresa?' Uma pergunta básica, tem empresário que não vai saber. E muitos vivem do negócio, ou seja, muitos não têm uma fonte de renda paralela para a família. Todo o padrão de vida é custeado pela empresa. Então 
a regra é: 'eu preciso de $x$ para viver, vou tirando'. Muitas vezes, nem sabe se a capacidade de geração de recurso da empresa é compatível com aquilo.

Infere-se que, na percepção do pesquisado, diversos micro e pequenos empreendimentos não realizam um controle efetivo sobre a extração de dinheiro do caixa da empresa, sendo que muitas vezes nem são capazes de informar o quanto foi tirado de recursos em um período. Mais uma vez, foi reforçada a questão da falta de informações sobre o negócio como um problema que impede o pequeno empresário de compreender a capacidade de geração de recursos de seu empreendimento.

Ainda com relação ao caixa, ao ser questionado sobre a existência, ou não, de um histórico de movimentações de caixa, o empresário contábil respondeu que muitas MPEs clientes mantêm algum tipo de registro, mesmo que artesanal. Na percepção do profissional, o sistema de caixa se popularizou atualmente, seja pela necessidade ou para atender as exigências da legislação fiscal. Apesar disso, o entrevistado complementa:

Então existe o registro. Mas eu diria que, na maioria dos casos, não existe a análise desse registro. [...] não existe um processamento dessa informação para fins de análises estratégicas do negócio. Então eu vejo como um controle quantitativo do caixa, mas não análise qualitativa das operações financeiras.

Nesse sentido, o relato aponta que não há uma gestão efetiva dos fluxos de caixa em grande parte das micro e pequenas empresas, ainda que essas mantenham um registro desses fluxos. No ponto em questão, o relato da pesquisa confirma os dados levantados por Martins (2014) em um estudo realizado com MPEs do Sudoeste do Paraná, que aponta que apenas $11 \%$ dos empreendimentos usavam informações do fluxo de caixa como uma ferramenta de controle interno.

Em seguida, foi realizado questionamento referente à aceitação de serviços de assessorias e consultorias financeiras oferecidas pelo escritório para suas clientes MPEs, ao que o empresário contábil respondeu tratar-se de um processo difícil e que possui dois principais limitadores, conforme segue:

Boa parte dessas empresas ainda trabalham, parcialmente, com informalidades. Ou seja, operações, infelizmente, ainda não fiscais, nem todas as operações são $100 \%$ conforme a legislação fiscal. Então, muitas vezes, existe um receio de procurar o profissional contábil [...]. Então, já existe esse primeiro limitador, sabe? E o segundo limitador é que, muitos dos empresários são autossuficientes. Eles entendem que, se o negócio chegou até agora, com os erros que ele prática e com a forma que ele gerencia, então é sinal que ele está acertando mais que errando. [...] Tem uma certa resistência de verificar isso, e até, muitas vezes, ouvir aquilo que não quer ouvir.

No que se refere ao segundo limitador, a chamada autossuficiência do micro e pequeno empreendedor, o entrevistado acrescentou que, enquanto profissional contábil contratado pela pessoa jurídica da empresa, ele possui o dever de apontar as falhas que vem percebendo no negócio. O que acontece, de acordo com o empresário contábil, é que alguns sócios e proprietários escolhem não aceitar esses apontamentos para evitar repercussões em sua qualidade de vida ou em sua vida familiar.

Ao ser questionado sobre os instrumentos de gestão financeira costumeiramente oferecidos aos clientes pelos escritórios sob sua direção, o empresário contábil alegou ter Prosppectus - Perspectivas Qualitativas em Contabilidade e Organizações. João Pessoa. v. 1, n. 1, p. 72 107, jul/2021. 
iniciado, há cerca de um ano e meio, a utilização de ferramentas tecnológicas que podem ser usadas pelos próprios clientes. De acordo com o profissional, faz-se uma análise do nível de maturidade do cliente, em três níveis: clientes que não têm nenhuma maturidade financeira, clientes com um nível intermediário, e clientes com uma retaguarda financeira melhor.

Tal divisão seria realizada para que todos os clientes recebessem acesso à plataforma sem enfrentar grandes dificuldades. Ao ser questionado sobre como funciona essa ferramenta, o profissional contábil informou que, no nível mais básico, os clientes alimentam a plataforma com algumas informações financeiras, anexando os comprovantes, e os escritórios conseguem ter acesso em tempo real. Já para os clientes de um nível intermediário só se faz a integração do sistema da própria empresa com o sistema oferecido pelos escritórios.

Já no caso de clientes com um bom nível de organização financeira, o empresário contábil comenta que:

A gente já parte mais para a análise, não precisa focar tanto em validação do
número, é um número mais confiável [...] nessa análise, são decisões mais
estratégicas, onde a gente vai demonstrar, em indicadores, se a empresa está
subindo, crescendo, do ponto de vista de números, de resultado, quais são as
contas mais representativas. Então basicamente a gente faz uma análise vertical
das contas, uma análise horizontal demonstrando a variação relativa à do
período anterior, e os principais índices financeiros: liquidez, endividamento,
produtividade [...]

Em outro trecho da entrevista, o profissional ressaltou que a maioria das organizações que já estão em nível de análise de suas demonstrações e indicadores não são micro e pequenas empresas, e sim, de médio e grande porte. No entanto, o relato da entrevista indica que os escritórios trabalham com as MPEs para começar a introduzir a importância da análise financeira para seus negócios.

No questionamento referente à elaboração e análise de demonstrações contábeis, foi informado que os sistemas financeiros utilizados pelos escritórios servem de base para a preparação desses relatórios. Entretanto, o empresário contábil mencionou, ainda, a dificuldade em obter informação financeira para o fechamento das demonstrações:

\footnotetext{
Porque informação de compras, de vendas, de folha de pagamentos, tudo isso a gente já tem, dentro da empresa contábil, pelos outros setores. [...] mas a parte de banco e de caixa, é muito do berço financeiro da empresa. Então, dificilmente, a gente vai ter acesso a essa informação. [...] então foi por isso que a gente investiu na contratação dessas ferramentas, para que elas coletem esse dado lá na origem, no financeiro do cliente, para que chegue com mais coerência.
}

Nesse sentido, depreende-se que ferramentas como a análise das demonstrações contábeis, por exemplo, não são muito aproveitadas pelas micro e pequenas empresas na percepção da profissional, uma vez que muitas informações financeiras não são facilmente disponibilizadas, conforme já indicado.

Em seguida, foi direcionado um questionamento sobre a solicitação e utilização de orçamentos pelos clientes, ao que foi respondido que, de todo o universo de 500 Prosppectus - Perspectivas Qualitativas em Contabilidade e Organizações. João Pessoa. v. 1, n. 1, p. 72 $107, \mathrm{jul} / 2021$. 
clientes, apenas 1 utiliza orçamentos, e se trata de uma empresa de grande porte. Em outro trecho, o entrevistado complementa que:

\begin{abstract}
A maioria desses empresários é acostumado a gerir o que acontece, não a prever. [...] Então eles sempre demonstram esse sentimento de que 'eu não posso prever o futuro, eu não tenho como me planejar, eu não tenho como ter essa perspectiva do que vá acontecer.' Então eles [...] se consideram sem base de fazer essa projeção futura. Não demonstram esse interesse.
\end{abstract}

Nesse ponto, a percepção do empresário contábil coincide com os resultados da pesquisa de Ishikaki (2003), que apontam que empreendimentos de pequeno porte geralmente consideram o orçamento como um instrumento altamente sofisticado e que deve ter sua utilização restrita a empresas maiores. Esse fato constitui um problema quando se considera a importância da utilização de ferramentas de planejamento, que quando não utilizadas, pode constituir um dos fatores de mortalidade para os pequenos negócios (Ferreira, Oliva, Santos, Grisi \& Lima, 2012).

\title{
4.3 Gestão Financeira: Contexto da Pandemia
}

Esta seção tem por objetivo verificar a percepção do empresário contábil quanto ao contexto da crise econômica proporcionada pela pandemia do coronavírus e seus impactos na gestão financeira nas micro e pequenas empresas, identificando os principais setores afetados e as dificuldades mais recorrentemente percebidas. Este tópico almeja, ainda, identificar a percepção do entrevistado quanto ao papel desempenhado, enquanto profissional contábil, em meio ao referido cenário.

De início, buscou-se identificar a opinião do empresário contábil quanto aos segmentos de MPEs mais afetados pelos efeitos econômicos da pandemia, entre seus clientes. Em resposta ao questionamento, o entrevistado levantou que um dos setores mais afetados foi o de supérfluos, ao que foram exemplificados: lojas de bolsas, calçados e artigos de luxo. Além deste, foram mencionados ainda os setores de papelaria, postos de combustíveis, hotéis, restaurantes, bares e lanchonetes.

Segundo o profissional, as causas para esse impacto podem estar na queda de demanda por parte da população decorrente do isolamento, bem como pelas medidas de lockdown que obrigaram a suspensão das atividades presenciais de alguns empreendimentos. Em contraste com esse cenário negativo, foi mencionada a existência de setores de MPEs que tiveram um maior crescimento durante a pandemia, conforme segue:

Então, tiveram segmentos que foram aquecidos pela pandemia, pela mudança do perfil do público consumidor, que acabou buscando produtos alternativos, tanto para ocupar o tempo quanto para ter uma renda extra também. Então esses setores que eu percebi crescerem mais foram esses do agro, de material de construção, gêneros alimentícios como um todo, e cosméticos [...]

Na visão do empresário contábil, apesar de muitos setores terem visto seus números decrescerem devido às repercussões negativas da pandemia, outros segmentos de mercado obtiveram no mesmo contexto um espaço maior para desenvolvimento. $\mathrm{Na}$

Prosppectus - Perspectivas Qualitativas em Contabilidade e Organizações. João Pessoa. v. 1, n. 1, p. 72 107, jul/2021. 
Joanne Victória Cavalcanti de Oliveira Ferreira; Christianne Calado Vieira de Melo Lopes

tabela3, a seguir, são resumidos os setores que foram mais afetados, bem como os que apresentaram expansão.

\section{Tabela 3}

Segmentos de Micro e Pequenas Empresas

\begin{tabular}{|l|l|}
\hline \multicolumn{1}{|c|}{ Segmentos mais afetados } & \multicolumn{1}{|c|}{ Segmentos em Expansão } \\
\hline Comércio de supérfluos & Agronegócio \\
\hline Hotelaria & Materiais de construção \\
\hline $\begin{array}{l}\text { Restaurantes, bares e } \\
\text { lanchonetes }\end{array}$ & $\begin{array}{l}\text { Gêneros alimentícios como um } \\
\text { todo }\end{array}$ \\
\hline Papelaria & Cosméticos \\
\hline Postos de combustíveis & - \\
\hline
\end{tabular}

Dentre as possíveis causas para a expansão do setor de material de construções, o entrevistado aponta para o isolamento, que manteve as pessoas em casa e as tornaram disponíveis para pequenas reformas. No que se refere ao crescimento do setor agro, por sua vez, foi mencionada uma empresa cliente do setor agrícola que cresceu mais de $40 \%$, por ter conquistado mais clientes pessoas físicas que começaram a desenvolver plantações em suas próprias casas, principalmente no interior do estado.

Quando questionado acerca das dificuldades mais frequentemente enfrentadas pelas micro e pequenas empresas clientes no contexto da crise atual, o empresário contábil indicou três maiores obstáculos: a dificuldade na aderência a ferramentas digitais, o acesso ao crédito, e a falta de dados para medição do negócio.

No que se refere à dificuldade de aderência a ferramentas digitais, o entrevistado comentou a resistência antiga dos empresários de submeterem-se a uma transformação digital, inclusive para o relacionamento com os próprios escritórios de contabilidade. Segundo o empresário, foi no ensejo da pandemia que a transformação digital começou a ser implantado no relacionamento com o cliente. Outro problema apontado com relação à tecnologia foi o próprio funcionamento das empresas em meio à crise. Para o entrevistado:

Então, essa trava para transformar as empresas em empresas.com. Porque, os decretos de lockdown proibiram muitas empresas de abrir, mas permitiam delivery. Só que muitas empresas não sabiam nem por onde começar, não tinham página no Instagram, não tinham site[...] não sabiam fazer essa parte de vendas online.

Nesse sentido, confirma-se o levantamento da Panorama (2020) e do estudo de Bernardes, Silva e Lima (2020), que apontou a migração para ambientes digitais como uma das maiores dificuldades enfrentadas pelas MPEs no cenário da pandemia. Em função desta dificuldade, observa-se uma queda nas vendas devido ao decreto de lockdown e por não vender de forma online. 
Quanto ao segundo obstáculo apontado, o acesso ao crédito, o empresário contábil comentou que, apesar da exaustiva divulgação de novas linhas de crédito por parte das esferas de governo, na realidade não foi o que bem aconteceu:

As empresas procuravam as instituições bancárias, mas as instituições não operacionalizavam bem os créditos, conforme mandava o figurino. E outra, muitas empresas devendo mesmo [...]. Se atrapalharam financeiramente, e aí não tinham uma certidão negativa, então não tinham acesso a crédito, então acabava virando uma bola de neve.

Por fim, foi comentado o terceiro obstáculo apontado, que seria a falta de dados para medição do negócio. Segundo o relato da entrevista, esse problema sempre foi presente, mas no contexto da crise intensificou-se, por tratar-se de um momento em que as empresas tiveram de tomar muitas decisões. Nas palavras do entrevistado, faltou por parte de alguns negócios, a "velocidade em tomada de decisão para agir de uma forma compatível numa nova realidade".

No ensejo dos questionamentos sobre as dificuldades enfrentadas, foi direcionada uma questão sobre a ocorrência, ou não, de situações de inadimplência no pagamento de honorários devidos ao escritório pelas MPEs clientes. O empresário contábil respondeu que houve inadimplência, especialmente por parte de empresas que tiveram que fechar as portas devido às restrições impostas pelo lockdown. Além do mais, o entrevistado destacou as dificuldades que a inadimplência passou a gerar nos próprios escritórios de contabilidade:

\begin{abstract}
Empresa que ficou quinze dias fechada já queria pagar metade do honorário contábil. [...] E faz um desafio para o micro e pequeno empresário contábil, olhando pelo outro lado, porque a grande maioria dos gastos das empresas contábeis são gastos fixos: salário, aluguel, softwares, encargos financeiros... tudo é meio que custo fixo. [...] sempre que há lockdown, a inadimplência aumenta. Então, teve lockdown, já é de praxe, pode se preparar financeiramente para uma inadimplência maior no período seguinte.
\end{abstract}

Referindo-se à inadimplência, o empresário contábil complementou em outro trecho que muitos clientes pleitearam redução de honorários pela perda na obtenção de receitas. Assim, de acordo com o profissional, os próprios escritórios de contabilidade acabaram também perdendo receita.

Quando questionado se alguma MPE cliente teve que encerrar as atividades de modo permanente em decorrência da crise, o entrevistado respondeu que houve diversas ocorrências do tipo. Empresas históricas, com décadas de existência, tiveram que fechar as portas, de acordo com o relato da entrevista.

Em seguida, foi realizado um questionamento acerca da situação dos estoques de clientes MPEs que tiveram que encerrar atividades com o público, devido às restrições de lockdown. A essa pergunta, o entrevistado respondeu que grande parte das empresas que trabalham com perecíveis do tipo alimentos, insumos agropecuários $\mathrm{e}$ medicamentos não tiveram tanto impacto no estoque, uma vez que normalmente se enquadravam como atividades essenciais. Contudo, o profissional relembrou a questão dos supérfluos, já citados: 
Mas você tem, por exemplo, na esfera dos supérfluos, bolsas, cintos, artigos de couro, que muitos produtos mofaram. Muitas lojas em shopping, que você tem um produto de couro, por exemplo que fica num estoque fechado sem arejar [...] sem circulação, sem a manutenção, e que vieram a estragar, danificar permanentemente. Alguns recuperáveis, outros não. [...] Tiveram muitos casos.

Quando questionado sobre a existência, ou não, de dificuldades percebidas pelos clientes MPEs para o recebimento de vendas realizadas a prazo, o empresário contábil comentou que a modernização dos meios de pagamento, como o uso do cartão de crédito, contribuiu para que o impacto da inadimplência nesse período fosse menor.

Todavia, o empresário contábil ressaltou que muitas empresas, em geral do interior, aplicam ainda a chamada política do "vale", onde a empresa financia seus clientes diretamente, seja por boleto bancário ou por cadernetas. Tratando-se desse tipo de empreendimento, na percepção do entrevistado, houve um aumento considerável na inadimplência.

Ainda no que se refere à inadimplência, o empresário contábil exemplificou a situação de uma indústria muito significativa no estado de Pernambuco, que é a indústria de confecções, em conformidade com pesquisas do SEBRAE (2012). Na percepção do profissional, houve um "efeito dominó" em toda a linha de produção, ainda que apenas um ponto dessa linha fosse obrigado a encerrar atividades devido às restrições de lockdown, conforme segue:

Então, por exemplo, indústrias de confecção, comercializam para lojista. Então a maioria delas, a venda é no boleto bancário. Então quando o lojista lá da ponta fez uma encomenda para ela de $n$ peças, ela [...] produziu, chegou na hora de entregar, muitas vezes eles dizem 'só manda metade, que eu estou fechado, não posso receber' ou 'não manda mais nada'. Então prejudicou toda uma linha de produção por trás por causa do lockdown lá da ponta, do varejo que está fechado. Então você afeta o distribuidor e afeta a indústria.

O empresário contábil ainda complementou que a informalidade e a ausência de contratos entre as empresas negociantes também são fatores que impactam na inadimplência, uma vez que não tem como se recorrer a esses cancelamentos de pedidos.

Foi direcionada uma questão que buscava identificar se os clientes MPEs buscaram o apoio dos escritórios para a tomada de decisões importantes durante o período da crise econômica. De acordo com o relato da entrevista, houve sim uma busca por parte dos pequenos clientes do auxílio dos escritórios para esclarecimento de dúvidas e tomada de decisões, especialmente no primeiro trimestre do início da crise, nos meses de março a junho de 2020. Nesse período, o entrevistado percebeu uma maior preocupação de seus clientes em assuntos referentes aos funcionários, conforme segue:

Então, os primeiros meses da pandemia, o contador foi o acolhedor de demandas de como rever os desembolsos com folha de forma a aliviar o caixa da empresa e de assegurar os empregos, que era também o grande peso para o empresário [...] muitos tinham funcionários recebendo salário-mínimo que era a única fonte de renda de uma família de seis ou oito pessoas. [...] Muitas vezes sem um auxílio família, sem um bolsa família.

Prosppectus - Perspectivas Qualitativas em Contabilidade e Organizações. João Pessoa. v. 1, n. 1, p. 72 107, jul/2021. 
Dando continuidade ao relato, o empresário contábil comentou que, a partir das publicações das primeiras medidas e normas referentes ao funcionamento de estabelecimentos, contratos de trabalho, dentre outros, os escritórios passaram a desempenhar um papel mais informativo a seus clientes. Pelas próprias linguagens técnicas utilizadas nas normas, foi relatado na entrevista, os clientes buscavam apoio dos escritórios para uma tradução e orientações sobre que medidas deveriam tomar.

Outro ponto comentado é que em muitas ocasiões, as linhas de comunicação com os escritórios congestionavam pela quantidade de clientes buscando informações capazes de sanar suas dúvidas, o que levou a adoção de meios de divulgação para atender melhor, conforme relato do profissional:

\begin{abstract}
Então eu fiquei, no início da pandemia, basicamente com esse papel. Saiu uma norma, traduzir, fazer um vídeo de um minuto explicando o que era, para meio que segurar essas dúvidas que iam vindo. Então a gente divulgava nas redes de distribuição, Whatsapp, a gente passou a usar e-mail [...] foi um papel crucial na reorganização do negócio diante do que a legislação permitia para essas empresas terem fôlego.
\end{abstract}

O empresário contábil ainda listou os tópicos mais significativos para o esclarecimento com os clientes, sendo os relativos à postergação de tributos, linhas de crédito, permissão de funcionamento ou não, e de legislação trabalhista e previdenciária. Com a utilização das ferramentas de divulgação, os escritórios passaram a ser, segundo o profissional, a principal fonte de informação para que os clientes MPEs tomassem decisões.

No ensejo do questionamento sobre o papel dos escritórios de contabilidade no apoio à tomada de decisões, foi realizada uma pergunta referente à carga de trabalho dos profissionais de contabilidade devido a essas novas procuras. De acordo com o empresário contábil, a carga aumentou consideravelmente, uma vez que além da rotina das obrigações a cumprir, surgiu um fator de apoio psicológico ao empresário para que ele pudesse tomar decisões da melhor forma possível.

Para que pudessem ser atendidos os clientes de maneira que os escritórios exercessem o papel de apoio, fornecendo segurança para a tomada de decisões, $o$ profissional destaca o fornecimento de capacitações aos colaboradores dos escritórios. Segundo o entrevistado:

Então a gente fez várias capacitações no escritório com relação à comunicação, como lidar com esse cliente [...] montou toda uma retaguarda para os colaboradores do ponto de vista psicológico, de segurança do trabalho, gestão em home office, para o colaborador [...] se sentir feliz, seguro, para poder contagiar o cliente com essa positividade. [...]

Ao fim da entrevista, o empresário contábil destacou que busca não entregar apenas balanços ou guias de recolhimento de impostos, e sim, utilizar uma linguagem que seja traduzível para o empresário.

Na visão do empresário contábil, houve um começo de utilização de uma linguagem dos negócios para a comunicação com os clientes, a partir da qual a contabilidade ultrapassou expressões meramente técnicas e passou a fornecer 
informações relevantes para a tomada de decisões. Nesse ponto, confirma-se a afirmação de Corrêa (2010) de que parte significativa das MPEs vem buscando o apoio de informações contábeis para a tomada de decisões, bem como a de Mendes (2020), que apontou que grande parte das MPEs pesquisadas considerava a contabilidade essencial para a sobrevivência de seus negócios, considerando positivos os serviços contábeis recebidos.

\section{SÍNTESE DOS RESULTADOS}

Com a aplicação da entrevista, foi possível verificar a percepção do empresário contábil quanto à gestão empresarial e financeira de micro e pequenas empresas.

Depreende-se que as principais dificuldades enfrentadas em contextos normais pelos gestores de pequenos negócios envolvem aspectos como a falta de profissionalização na gestão e a ausência de análises de dados dos negócios. Na percepção do entrevistado, grande parte dos gestores de MPEs possui uma noção básica de gestão financeira, mas não um conhecimento de nível estratégico.

No que se refere à gestão financeira, identificou-se que muitas MPEs não distinguem o patrimônio da empresa do patrimônio de seus sócios, o que leva a problemas de caixa. Além do mais, as informações dos registros de caixa também não costumam ser aproveitadas para fins de tomada de decisões.

Quanto à aceitação dos serviços de apoio na gestão financeira ofertados pelos escritórios, as MPEs ainda apresentam certa resistência, seja pela informalidade dos seus negócios ou pelo sentimento de autossuficiência do proprietário. Entretanto, os escritórios vêm buscando trabalhar com seus clientes a utilização de ferramentas tecnológicas para fins de organização financeira, através da alimentação de planilhas e integração de sistemas, portanto, percebe-se que há um esforço em oferecer, por parte do escritório, uma assessoria contábil- financeira de qualidade, destacado pelo estudo de Dominguez, Tinoco, Yoshitake, Paulo e Claro (2017).

Para empresas com uma maior retaguarda financeira, são ofertados relatórios com análises de suas demonstrações e oferta de indicadores. Todavia, poucas MPEs encontram-se nesse nível, uma vez que há maior dificuldade na obtenção das informações de nível financeiro, conforme apontando, também, pelo estudo de Santos, Ferreira e Faria (2009).

No que se refere à utilização de orçamentos, concluiu-se que nenhuma micro e pequena empresa cliente trabalha com projeções e previsões futuras, o que indica que muitos gestores ainda partilham a visão de que essa ferramenta não é aplicável para pequenos negócios.

Com relação aos segmentos de MPEs mais afetados pela crise econômica atual, identificou-se os setores de supérfluos, papelaria, postos de gasolina e restaurantes. Por outro lado, verificou-se crescimento em agronegócio e material de construção, dentre outros. Quanto às dificuldades mais enfrentadas pelas MPEs no contexto atual, encontram-se a dificuldade na migração para ambientes digitais, no qual também foi Prosppectus - Perspectivas Qualitativas em Contabilidade e Organizações. João Pessoa. v. 1, n. 1, p. 72 107, jul/2021. 
destacado por Bernardes, Silva e Lima (2020), além dos obstáculos no acesso ao crédito e ausência de dados para medição do negócio.

Verificou-se a existência de situações de inadimplência por parte de clientes MPEs no que se refere aos honorários devidos aos escritórios de contabilidade. Nesse sentido, o próprio micro e pequeno empresário contábil vêm lidando com dificuldades financeiras para pagamento de custos fixos e redução na obtenção de receitas conforme citado por Sehnem, Magro, Mazzioni, Joveci Filho, Lunkes e Zanella (2021).

Apurou-se também que muitos pequenos empreendimentos históricos que eram clientes tiveram que encerrar suas atividades de modo permanente. Quanto aos estoques de MPEs afetadas pelas medidas de lockdown, concluiu-se que várias lojas apresentaram perdas em produtos supérfluos, como artigos de couro. Constatou-se, ainda, que muitas MPEs enfrentaram inadimplência por parte de seus clientes, especialmente as que trabalham com meios mais antigos de pagamento, como a utilização de vales e cadernetas de anotação.

A pandemia do Covid 19 trouxe, ao ambiente empresarial, alto níveis de incertezas para gerenciar suas atividades diante deste evento inesperado, e a partir do estudo realizado, observou-se que houve um aumento na procura pelo apoio do profissional contábil para a tomada de decisões pelas MPEs, corroborando com o entendimento da Teoria da Contingência da Contabilidade Gerencial, destacado por Otley (2016). Outras temáticas com demandas para esclarecimentos por parte do empresário contábil, neste momento de mudança de cenário, tem-se: prorrogação no pagamento de tributos; obtenção de linhas de crédito; permissão de funcionamento; e tópicos referentes à legislação trabalhista e previdenciária. Portanto, depreende-se que houve um aumento na carga dos profissionais contábeis colaboradores dos escritórios.

\section{CONSIDERAÇÕES FINAIS}

O ambiente de incerteza ambiental, fator contingencial, observado neste estudo gerado pela pandemia do Covid 19, fez com que as empresas enfrentassem as incertezas surgidas a cada dia, buscando se adaptar e enfrentar os desafios financeiros surgidos decorrentes da crise econômica gerada. Diante deste cenário, o estudo buscou responder ao seguinte problema de pesquisa: Como a pandemia da COVID impactou na gestão financeira das micro e pequenas empresas sob a ótica de um empresário contábil?

Para alcançar o objetivo norteador deste trabalho foi necessária a realização de pesquisa documental, por meio de uma entrevista com um empresário contábil, permitindo apresentar os seguintes resultados quanto aos impactos da COVID-19 enfrentados pelas MPEs quanto à gestão financeira: redução na obtenção de receitas, devido aos decretos determinados pelo governo e dificuldade de migrar as vendas para os meios digitais; inadimplência por parte de seus clientes, especialmente os que trabalham com meios mais antigos de pagamento, como a utilização de vales e cadernetas de anotação, bem como obstáculos nas obtenção das linhas de crédito por parte das esferas do governo. 
Por meio do estudo foi possível verificar que os gestores de MPEs já enfrentam grandes dificuldades na condução de seus negócios em contextos normais, principalmente em decorrência da ausência de análise de dados dos negócios e gestão pouco profissionalizada. Com a nova realidade imposta pela pandemia, logo, um novo ambiente de incerteza estratégica, os desafios se ampliaram, envolvendo a necessidade de transformações digitais e, mais do que nunca, a utilização de dados capazes de medir o negócio e servir como base para tomada de decisão.

Esta pesquisa contribui para a discussão da temática sobre a crise proporcionada pela pandemia para as MPEs, uma vez que houve a promulgação de novas medidas em função dos muitos aspectos do mercado que foram alterados, desta forma, criando um ambiente de incertezas, tornando-se necessária uma rápida divulgação de informações contábeis. Nesse contexto, o aumento pelos serviços prestados pelos escritórios de contabilidade, indica a relevância das informações contábeis para a execução de um papel de apoio na tomada de decisões e na gestão de recursos financeiros de micro e pequenos empreendimentos. Desse modo, reforça-se o papel da contabilidade enquanto ferramenta de gestão capaz de ofertar serviços essenciais contábeis e financeiros que contribuem para a sobrevivência das MPEs.

Como limitações deste estudo, podem ser apontadas a existência de outras categorias a serem pesquisadas, quanto ao foco financeiro, que deixaram de ser abordados. No entanto, diante do objetivo proposto neste estudo, acredita-se que os resultados foram satisfatórios. Para pesquisas futuras, sugere-se a ampliação da investigação, aplicandose entrevistas com mais empresários contábeis, bem como mudar o foco do estudo, partindo da investigação sob o prisma dos micros e pequenos empresários, para fins de comparação.

\section{REFERÊNCIAS}

Andrade, I. R. S. (2020). Orçamento empresarial e planejamento estratégico. Salvador: UFBA.

Assaf Neto, A. (1997). A dinâmica das decisões financeiras. Caderno de estudos, 16, 01-17. Bardin, L. (1977). Análise de conteúdo. Lisboa: Edições 70.

Belizário, M. P. \& Almeida, S. R. (2020). O impacto da COVID-19 no índice de mortalidade de micro e pequenas empresas. Anais do XVII Congresso USP de Iniciação Científica em Contabilidade. São Paulo: USP, 2020.

Bernardes, J.; Silva, B.; \& Lima, T. (2020). Os impactos financeiros da Covid-19 nos negócios. Revista da FAESF, Floriano, Número Especial COVID-19, 4, 43-47, 2020.

Bonacim, C. A., Grespan, C. J. A. C., \& Corrêa, H. L. (2009). Mortalidade dos empreendimentos de micro e pequenas empresas: causas e aprendizagem. Gestão\& Regionalidade, São Caetano do Sul., 25, 61-78. https://doi.org/10.13037/gr.vol25n74.220. 
Joanne Victória Cavalcanti de Oliveira Ferreira; Christianne Calado Vieira de Melo Lopes

Brasil. (2006). Lei Complementar n⿳0 123, de 14 de dezembro de 2006. Institui o Estatuto Nacional da Microempresa e Empresa de Pequeno Porte e dá outras providências. Diário Oficial da União, Poder Executivo, Brasília, 15.12.2006.

Brigham, Eugene F. (1999). Fundamentos da moderna administração financeira. São Paulo: Campos.

Brito, P. E. P. (2005). Administração do capital de giro: sua importância no resultado da empresa. 83 f. Monografia (Bacharelado em Administração de Empresas) - Centro Universitário de Brasília. Brasília.

Brizolla, M. M. B. (2008). Contabilidade gerencial. Ijuí: Unijuí.

Camargo, R. F. (2018). Análise horizontal e vertical das demonstrações contábeis: informações essenciais podem ser encontradas. Treasy. Recuperado em 17 mar. 2021de: https://www.treasy.com.br/blog/analise-horizontal-e-analise-vertical/

Carneiro, M. (2015). Orçamento empresarial. Rio de Janeiro: SESES.

Child, J. (1975) Managerial and organizational factors associated with company performance-part II. A contingency analysis. Journal of Management Studies, 12, 1-2, 12 27. https://doi.org/10.1111/j.1467-6486.1975.tb00884.x.

CPC.Comitê de Pronunciamentos Contábeis. (2010). Pronunciamento técnico CPC 03 (R2): Demonstração dos fluxos de caixa. Recuperado em 19 fev. 2021 de https://www.cpc.org.br.

Corrêa, L. P. F. (2010). O uso da contabilidade gerencial como ferramenta de gestão nas pequenas e médias empresas da região da AMREC. $91 \mathrm{f}$. Monografia (Bacharelado em Ciências Contábeis) - Universidade do Extremo Sul Catarinense. Criciúma, 2010.

Dresch, A.; Lacerda, D. P. \&Antunes Júnior, J. A. V. (2015). Design Science Research: método de pesquisa para avanço da ciência e tecnologia. Porto Alegre: Bookman.

Donaldson, L., (2012). Teoria da Contingência Estrutural. In: CLEGG, S. R.; HARDY, C.; NORD, W. R. (org.). Handbook de Estudos Organizacionais: modelos de análises e novas questões em estudos organizacionais. São Paulo: Atlas.

Domingues, O. G. D., Tinoco, J. E. P., Yoshitake, M., Paulo, W. L. \& Claro, J. A. C. S. (2017). Gestão de Capital de Giro e Formação do Preço de Venda Praticado pelas Micro e Pequenas Empresas. Revista Ambiente Contábil, 9, 77-96. https://doi.org/10.21680/21769036.

Feil, A. A. \& Haberkamp, A. M. (2020). Análise do nível de importância e das variáveis intervenientes na utilização de ferramentas gerenciais em micro e pequenas empresas. Revista da micro e pequena empresa (RMPE). 14, 3, 120-133. Recuperado em 14 jun 2021 de: http://dx.doi.org/10.48099/1982-2537/2020v14n3p120133.

Ferreira, C. C., Macedo, M. A. S., Sant'anna, P. R., Longo, O. C. \& Barone, F. M. (2011). Gestão do capital de giro: contribuição para as micro e pequenas empresas no Brasil. BrazilianJournalofPublicAdministration, 45, 863-884. 
Joanne Victória Cavalcanti de Oliveira Ferreira; Christianne Calado Vieira de Melo Lopes

Ferreira, L. F. F., Oliva, F. L., Santos, S. A.; Grisi,C. C. H. \&Lima, A. C. (2012). Análise quantitativa sobre a mortalidade precoce de micro e pequenas empresas da cidade de São Paulo. Gestão \& Produção, São Carlos, 19, 811-823. https://doi.org/10.1590/S0104530X2012000400011.

FIPECAFI. (2018). Manual de contabilidade: aplicável a todas as sociedades. 3 ed. Atlas. São Paulo.

Fiorelli, T. P. (2016). A importância do controle do fluxo de caixa para as pequenas empresas da cidade de Videira. 62 f. Monografia (Especialização em Administração Estratégica e Financeira)- Universidade do Oeste de Santa Catarina. Videira, SC.

Fontana, F. (2018). Técnicas de pesquisa. Mazucato, T. (org.). Metodologia da pesquisa e do trabalho científico. Penápolis: FUNEPE. Recuperado em 6 jun 2021 de https://www.funepe.edu.br/site/5/livros/

Freitag, V. C., Almeida, K. K. N. \& Lucena, W. G. L. (2021). Teoria da Contingência. In: Almeida, K. K. N., França, R. D. (organizadores). Teorias aplicadas à pesquisa em contabilidade: uma introdução às teorias econômicas, organizacionais e comportamentais. João Pessoa: Editora UFPB.

Gazzoni, E. I. (2003). Fluxo de caixa: ferramenta de controle financeiro para a pequena empresa. 96 f. Dissertação (Mestrado em Engenharia da Produção) - Universidade Federal de Santa Catarina, Florianópolis, SC, 2003.

Gil, A. C. (2002). Como elaborar projetos de pesquisa. São Paulo: Atlas.

Gitman, L. J. (2010). Princípios de Administração Financeira. 12. ed. São Paulo: Pearson.

Governo Federal. (2020). Governo anuncia medidas de ajuda econômica para micro e pequenas empresas. Recuperado em 22 jun. 2021 de: <https://www.gov.br/ptbr/noticias/financas-impostos-e-gestao-publica/2020/03/governo-anuncia-medidas-deajuda-economica-para-micro-e-pequenas-empresas>.

Hoss, O. (2020). Gestão Financeira: Construção da Informação da Riqueza. 5 ed. Cascavel: DRHS Editora, 2020.

Ishisaki, N. (2003). A utilização do orçamento empresarial: um estudo em empresas da região do Vale do Paraíba - SP. 2003. 203 f. Dissertação (Mestrado em Administração de Empresas) - Universidade de Taubaté. Taubaté.

Iudícibus, S., Martins, E., \& Carvalho, L. N. (2005). Contabilidade: aspectos relevantes da epopéia de sua evolução. Revista Contabilidade \& Finanças, 16, 7-19.

Jornal contábil. (2021). Programa de redução de jornada e salário volta em 2021.Recuperado em 16 abr. 2021 de: <https://www.jornalcontabil.com.br/programa-de-reducao-dejornada-e-salario-volta-em-2021/>

Kuhn, I. N. (2012). Gestão Financeira. Ijuí: Unijuí. 
Joanne Victória Cavalcanti de Oliveira Ferreira; Christianne Calado Vieira de Melo Lopes

Kummer, A. A., Bromberger, D., \& Dondoni, P. C. (2011). A utilização das ferramentas de gestão financeira nas empresas: o caso das micro e pequenas empresas da cidade de São João no Sudoeste do Paraná. Revista CAP, 5, 26-32.

Martins, A. (2014). A utilização das ferramentas da gestão financeira nas empresas: análise das micro e pequenas empresas da cidade de Pato Branco no Sudoeste do Paraná. 2014. 66 f. Trabalho de Conclusão de Curso (Bacharelado em Ciências Contábeis) Universidade Tecnológica Federal do Paraná. Pato Branco

Mendes, S. D. (2020). A importância da contabilidade como instrumento de gestão nas empresas: uma análise dos impactos do coronavírus nas micro e pequenas empresas da cidade de João Pessoa/PB. 41 f. Trabalho de Conclusão de Curso (Bacharelado em Ciências Contábeis) - Universidade Federal da Paraíba. João Pessoa.

Miranda, L.C., Libonati, J. J., Freire, D. R., \& Saturnino, O. (2008). Demandas por serviços contábeis pelos mercadinhos: são os contadores necessários? Contabilidade Vista E Revista, 19, 131-151.

Nassif, V. M. J., Corrêa, V. S., \& Rossetto, D. E. (2020). Are Entrepreneurs and Small Businesses Prepared for Contextual Adversities? A Reflection in the Light of the Covid19 Pandemic. Iberoamerican Journal of Entrepreneurship and Small Business, 9(2), I-XII. Recuperado em 16 mar. 2021 de: https://doi.org/10.14211/regepe.v9i2.1880.

Otley, D. (2016). The contingency theory of management accounting and control: 19802014. Management Accounting Research,Lancaster, 31, 45-62. https://doi.org/10.1016/j.mar.2016.02.001.

Panorama PMEs: Os impactos da COVID-19 e os passos para a retomada. (2020). Recuperado em 16 mar. 2021 de: https://resultadosdigitais.com.br/materiaiseducativos/ebooks/panorama-pmes-os-impactos-da-covid-19-e-os-passos-para-aretomada/.

Prado Junior, C. (1981). História econômica do Brasil. São Paulo: Brasiliense.

Roratto, R., Dias, E. D., \& Alves, E. B. (2017). Mortalidade em micro e pequenas empresas: um estudo de caso na Região Central do Rio Grande do Sul. RevistaEspacios, Caracas, 38, 1-11.

Ross, S. A., Westerfield, R. W., Jaffe, J., \& Lamb, R. (2015). Administração financeira.10. ed. AMGH Editora.

Sá-Silva, J. R., Almeida, C. D.\& Guindani, J. F. (2009). Pesquisa documental: pistas teóricas e metodológicas. Revista Brasileira de História \& Ciências Sociais. n. I, p. 1-15, jul., 2009.

Santos, L. M.; Ferreira, M. A. M., \& Faria, E. R. (2009). Gestão financeira de curto prazo: Características, instrumentos e práticas adotadas por micro e pequenas empresas. Revista de administração da UNIMEP, São Paulo, 7, 70-92.

SEBRAE. Serviço Brasileiro de Apoio às Micro e Pequenas Empresas. (2012). Estudo econômico do arranjo produtivo local de confecções do Agreste Pernambucano. Recife:

Prosppectus - Perspectivas Qualitativas em Contabilidade e Organizações. João Pessoa. v. 1, n. 1, p. 72 $107, \mathrm{jul} / 2021$. 
SEBRAE. Recuperado em 22 jun. 2021 de:

https://www.sebrae.com.br/Sebrae/Portal\%20Sebrae/Anexos/Estudo\%20Economico\%2 0do\%20APL\%20de\%20Confeccoes\%20do\%20Agreste\%20-

\%20\%2007\%20de\%20MAIO\%202013\%20\%20docx.pdf.

SEBRAE. Serviço Brasileiro de Apoio às Micro e Pequenas Empresas. (2013). Anuário do trabalho nas micro e pequenas empresas. Brasília: SEBRAE. Recuperado em 16 mar. 2021 de:

https://www.sebrae.com.br/Sebrae/Portal\%20Sebrae/Anexos/Anuario\%20do\%20Trabal ho\%20Na\%20Micro\%20e\%20Pequena\%20Empresa_2013.pdf .

SEBRAE. Serviço Brasileiro de Apoio às Micro e Pequenas Empresas. (2016).

Sobrevivência das empresas no Brasil. Brasília: Sebrae. Recuperado em 28 jan. 2021 de: https://www.sebrae.com.br/Sebrae/Portal\%20Sebrae/Anexos/sobrevivencia-dasempresas-no-brasil-102016.pdf.

SEBRAE. Serviço brasileiro de apoio às micro e pequenas empresas. (2020a.) Estudo sobre participação de micro e pequenas empresas na economia, FGV Projetos. Brasília: Sebrae. Recuperado em 02 fev. 2021 de: https://datasebrae.com.br/wpcontent/uploads/2020/04/Relat\%C3\%B3rio-Participa\%C3\%A7\%C3\%A3o-mpe-pibUF2_compressed.pdf.

SEBRAE. Serviço brasileiro de apoio às micro e pequenas empresas. (2020b). Veja as medidas de apoio do governo aos pequenos negócios. Brasília: SEBRAE. Recuperado em16 abr. 2021 de: https://www.sebrae.com.br/sites/PortalSebrae/artigos/veja-as-medidas-deapoio-do-governo-aos-pequenos negocios,e5a9721df5b41710VgnVCM1000004c00210aRCRD.

SEBRAE. Serviço brasileiro de apoio às micro e pequenas empresas. (2020c). FGV Projetos. O impacto da pandemia de coronavírus nos pequenos negócios. FGV Projetos. 9ed. Brasília: SEBRAE. Recuperado em 27 mai. 2021 de: https://fgvprojetos.fgv.br/sites/fgvprojetos.fgv.br/files/impacto_coronavirus_nas_mpe_ 9aedicao_diretoria_v3_1.pdf.

SEBRAE. Serviço brasileiro de apoio às micro e pequenas empresas. (2021a). FGV Projetos. O impacto da pandemia de coronavírus nos pequenos negócios. 10a ed. FGV Projetos. Sebrae. Recuperado em 17 abr. 2021de: https://datasebrae.com.br/wpcontent/uploads/2021/03/Impacto-coronav\%C3\%ADrus-nas-MPE10\%C2\%AAedicao_DIRETORIA-v4.pdf.

SEBRAE.Serviço brasileiro de apoio às micro e pequenas empresas. (2021b). Pequenos negócios em segmentos mais vulneráveis à crise do coronavírus. Painel SEBRAE. Recuperado em18 mar. 2021 de: https://paineis-lai.sebrae.com.br/single/?appid=f9c6ba40-ae97-4aee804e-2eff863f4a6f\&sheet=ce0f6f6d-5f3f-45e1-a4bd$31363554586 \mathrm{~b} \&$ op $\mathrm{t}=$ currsel\&select $=$ clearall.

Sehnem, S., Magro, C. B. D., Mazzioni, S., Joveci Filho, Lunkes, R. \& Zanella, A. C. (2021). Capacidade de adaptação das empresas em um cenário de crise. Revista Gestão 
Organizacional, 14, 1, 33-53. Recuperado em 15 jun. 2021 de https://doi.org/10.22277/rgo.v14i1.5995.

Silva, D. J. C.; Miranda, L. C., Freire, D. R., \& Anjos, L. C. M. (2010). Para que serve a informação contábil nas micro e pequenas empresas? Revista Contemporânea de Contabilidade, 7, 89-106. https://doi.org/10.5007/2175-8069.2010v7n13p89.

Silva, D. Z. G., \& Neiva, R. M. (2010). O fluxo de caixa como ferramenta de gestão financeira e estratégica nas empresas. Revista da Faculdade de Administração e Economia, 2, 23-35. https://doi.org/10.15603/2176-9583/refae.v2n1p23-35.

Silva, M. P., Couto, C. H. M. \& Cardoso, A. A. B. (2016). Análise das demonstrações contábeis como ferramenta de suporte à gestão financeira. Revista Brasileira de Gestão e Engenharia, 13, 23-45.

Simons, R. (2005). Levers of Organization Design. HBS Press.

Söthe, A., \& Kamphorst, C. (2009). O orçamento empresarial como ferramenta de gestão nas micro e pequenas empresas do município de Mondaí - SC. Revista Catarinense da Ciência Contábil, 8, 09-22. http://dx.doi.org/10.16930/22377662/rccc.v8n24p9-22.

Souza, J. H.; Machado, L., \& Oliveira; C. A. S. (2007). As origens da pequena empresa no Brasil. Revista da Micro e Pequena Empresa, Campo Limpo Paulista, 1, 53-65. https://doi.org/10.6034/18.

Vale, F. N., Sousa, J. C., Oliveira, A. M. B., Regis, S. V. C. R \& Lima, J. S. S. (2021). O Impacto da Covid-19 mediado pela resiliência humana em microempreendores do ramo da beleza. Revista Gestão Organizacional. 14, 1, 212-230. Recuperado em 15 jun. 2021 de https://doi.org/10.22277/rgo.v14i1.5488 .

Wenzel, M., Stanske, S., \& Lieberman, M.B. (2020). Strategic responses to crisis. Strategic Management Journal, 41, 7-18. Recuperado em 15 jun 2021 de https://doi.org/10.1002/smj.3161

Zdanowicz, J. E. (1995). Fluxo de caixa: uma decisão de planejamento e controle financeiro. 6 ed. Porto Alegre: D C Luzzatto. 
Joanne Victória Cavalcanti de Oliveira Ferreira; Christianne Calado Vieira de Melo Lopes

\title{
DOCUMENTO SUPLEMENTAR
}

\author{
APÊNDICE 1 - Roteiro da entrevista
}

Contextualização: A presente pesquisa tem por objetivo identificar a percepção do empresário/profissional contábil quanto à gestão financeira de micro e pequenas empresas em meio à pandemia. A realização da entrevista é feita com gravação para posterior transcrição do áudio.

Pesquisadoras: Joanne Victória Cavalcanti de Oliveira Ferreira e Christianne Calado Vieira de Melo Lopes

\section{SEÇÃO 1 - IDENTIFICAÇÃO DO PERFIL DO PROFISSIONAL CONTÁBIL E DO ESCRITÓRIO}

Objetivo: identificar informações relativas ao perfil da entrevistada, bem como dados referentes aos escritórios que encontram-se atualmente sob sua gestão.

1- Há quanto tempo trabalha na área de contabilidade?

2- Qual o número de funcionários?

3- Qual o número de clientes, e mais especificamente, o número de micro e pequenas empresas atendidos atualmente?

\section{SEÇÃO 2 - PERCEPÇÃO QUANTO À GESTÃO EMPRESARIAL DE MPES}

Objetivo: identificar a percepção da profissional contábil quanto à gestão empresarial de MPEs, incluindo as dificuldades percebidas em contextos normais e o nível de conhecimento dos clientes quanto à gestão financeira.

1- Ainda não considerando o contexto da pandemia, quais as principais dificuldades que você percebe que seus clientes MPEs mais enfrentam na condução de seus negócios?

2- Na sua percepção, os clientes MPEs têm um bom conhecimento em práticas de gestão financeira?

\section{SEÇÃO 3 - GESTÃO FINANCEIRA: CONTEXTO GERAL}

Objetivo: identificar a percepção da entrevistada quanto a aspectos gerais relacionados à gestão financeira em MPEs, assim como a oferta de instrumentos de apoio pelos escritórios de contabilidade e sua utilização pelos clientes. 
Joanne Victória Cavalcanti de Oliveira Ferreira; Christianne Calado Vieira de Melo Lopes

1- Na sua percepção, há separação do caixa da empresa do caixa do proprietário, em respeito ao princípio da entidade, por parte de clientes MPEs?

2- Os clientes costumam organizar as movimentações de caixa, como um histórico?

3- Os clientes MPEs aceitam consultorias/assessorias financeiras oferecidas pelo escritório?

4- Quais os instrumentos de gestão financeira o escritório costuma oferecer a seus clientes?

5- Os clientes MPEs solicitam a elaboração de demonstrações contábeis?

6- Os clientes MPEs solicitam orçamentos?

$7-$

\section{SEÇÃO 4 - GESTÃO FINANCEIRA: PANDEMIA}

Objetivo: averiguar a percepção da entrevistada no que se refere ao contexto da crise econômica decorrente da pandemia do coronavírus e suas repercussões nas micro e pequenas empresas, identificando os principais setores afetados e as dificuldades mais frequentemente percebidas. Esta seção também visa identificar a percepção da entrevistada quanto ao papel desempenhado, enquanto profissional contábil, em meio ao referido contexto.

1- Em meio à crise proporcionada pela pandemia, dentre os setores de mercado (comércio, indústria, serviços), qual foi o mais afetado entre seus clientes MPEs?

2- No cenário atual, quais as principais dificuldades enfrentadas pelas MPEs que você pode notar?

3- Ocorreram situações de inadimplência por parte de MPEs clientes no pagamento de honorários devidos ao escritório de contabilidade?

4- Ocorreram situações em que MPEs clientes que tiveram que encerrar suas atividades permanentemente devido à crise?

5- Quanto a clientes que trabalham com estoques, como você percebeu a situação de MPEs que tiveram que encerrar suas atividades com portas abertas aos clientes?

6- Quanto a MPEs que trabalham com vendas a prazo, foram percebidas dificuldades para que estas recebessem pagamentos de seus clientes?

7- Os clientes MPEs buscaram seu apoio em alguma tomada de decisões nesse período?

8- Nesse contexto, você considera que houve um aumento na carga de trabalho dos colaboradores do escritório? 


\section{NOTAS}

\section{Contribuição de Autoria}

\begin{tabular}{|l|l|l|}
\hline Contribuição & $\begin{array}{c}\text { Joanne Victória } \\
\text { Cavalcanti de } \\
\text { Oliveira Ferreira }\end{array}$ & $\begin{array}{c}\text { Christianne Calado } \\
\text { Vieira de Melo } \\
\text { Lopes }\end{array}$ \\
\hline 1. Definição do problema de pesquisa & $\mathrm{X}$ & $\mathrm{X}$ \\
\hline 2. Fundamentação Teórica/Revisão de Literatura & $\mathrm{X}$ & $\mathrm{X}$ \\
\hline 3. Definição dos procedimentos metodológicos & $\mathrm{X}$ & $\mathrm{X}$ \\
\hline 4. Coleta de dados & $\mathrm{X}$ & \\
\hline 5. Análise e interpretação dos dados & $\mathrm{X}$ & $\mathrm{X}$ \\
\hline 6. Revisão crítica do artigo & $\mathrm{X}$ & $\mathrm{X}$ \\
\hline 7. Escrita do artigo & $\mathrm{X}$ & $\mathrm{X}$ \\
\hline 8. Outros (especificar) & & \multicolumn{2}{|l|}{} \\
\hline
\end{tabular}

\section{Editores}

Editora Geral: Viviane da Costa Freitag

Editora Adjunta: Karla Katiuscia Nóbrega de Almeida

\section{Histórico}

Recebido em: 01/06/2021

Revisado por pares em: 07/06/2021

Reformulado e recomendado para publicação: 02/07/2021

Publicado em: 30/07/2021

Prosppectus - Perspectivas Qualitativas em Contabilidade e Organizações. João Pessoa. v. 1, n. 1, p. 72 107, jul/2021. 